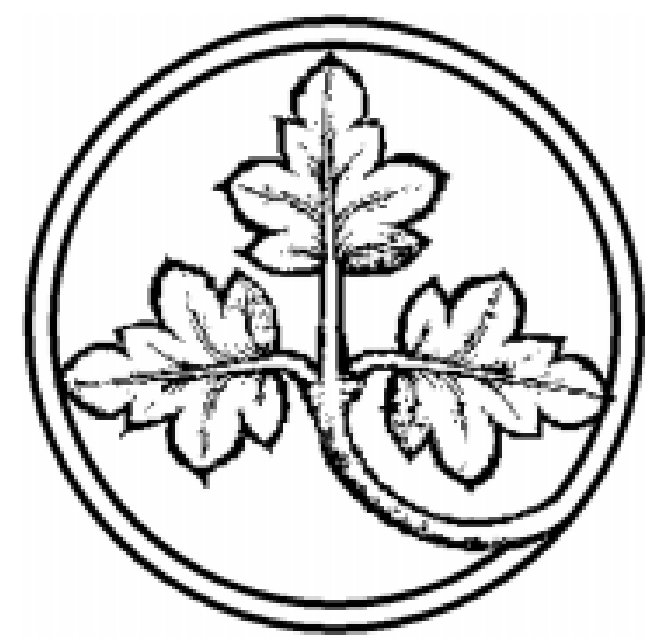

Gemeinschaftsgüter: Recht, Politik und Ökonomie

\author{
Preprints \\ aus der Max-Planck-Projektgruppe \\ Recht der Gemeinschaftsgüter \\ Bonn \\ 2002/15
}

Renewable Energy Policy in the United Kingdom and in Germany

André Suck 


\section{Renewable Energy Policy in the United Kingdom and in Germany ${ }^{1}$}

\section{Introduction}

The national energy industries, comprised of the gas and electricity markets, are currently facing two challenges, which require that they and their governments provide for new policy solutions. One challenge is to introduce more competitive market structures into the respective sectors against the background of an Internal Energy Market (IEM) ${ }^{2}$ in Europe. The abolition of trade barriers, both internationally between countries and nationally within formerly monopolistic market structures, will improve efficiency and productivity in the energy sector and result in general welfare gains that benefit the respective economy and society. The other challenge concerns the issue of sustainability. ${ }^{3}$ This issue has increasingly influenced this sectoral policy since it was established in the late 1980s. The increasing relevance of sustainability strategies in the energy sector is especially due to the growing seriousness of the problem of global warming. Related to this, one pivotal strategy evoked by the energy industry to combat global warming has been to increase the use of renewable energy technologies in electricity generation (Eyre 1998; Groscurth and Weinreich 1998). Renewable energy technologies comprise generation installations that use non-fossil resources, which are unendingly available (e.g. solar energy, geothermal energy, biomass, wind and hydro). The electricity generation processes from these sources do not cause climate-damaging greenhouse gas emissions such as $\mathrm{CO}_{2}$; they therefore represent sustainable forms of energy generation.

In this article I will analyse the development of the renewable energy policy in the United Kingdom and Germany against the background of the newly created competitive energy markets. Whereas other social and political research has already found great heterogeneity in the national regulatory regimes of the energy network industry (Schneider 1999; Eberlein 2000; Eising 2001;

1 This article originated out of the research project "Regulatory Regimes in Europe - The Process and the Impact of the Liberalisation of Network Industries", which is jointly organised by the London Business School and the Max Planck Project "Common Goods: Law, Politics and Economics". For helpful comments I am particularly indebted to Adrienne Héritier, Christoph Engel, Michael Bauer, Dominik Böllhoff, Katharina Holzinger, Florian Becker and Dieter Kerwer. I would also like to thank Darrell Arnold for his editorial help on this version.

2 The development of an Internal Energy Market started in 1988 when a package of directives was developed dealing with the issue of opening access to the gas and electricity supply. These directives were followed by further proposals aimed at increasing competition in the domestic markets (Matláry 1997). The two crucial steps for liberalising the European energy market were the adoption of the Community Directive 96/92/EC in 1996 for opening the electricity markets and the Community Directive 98/30/EC for opening the gas markets in 1998.

3 The term sustainability (or sustainable development) was first mentioned in the Brundtland Report for the World Commission on Environment and Development in 1987, where it was rather generally defined as development, which "seeks to meet the needs and aspirations of the present without compromising the ability to meet those of the future.... [P]olicy makers guided by the concept of sustainable development will necessarily work to assure that growing economies remain firmly attached to their ecological roots and that these roots are protected and nurtured so that they may support growth over the long term" (Brundtlandt 1987). This rather broad interpretation of this policy idea has been subject to a variety of interpretations, sharing "the common assumption that economic development and environmental protection are interdependent and that they need to be made compatible. (...) The mainstays of shift to sustainable development are believed to be policy actions which make both economic and environmental sense, so-called "no-regrets" options (also frequently referred to as "win-win" situations, or the 'double dividend')' (Collier 1998). 
Böllhoff 2002), here I shall focus on describing and explaining different regulatory approaches (Coen and Thatcher 2000) that aim to achieve an increasingly sustainable industry sector by extending the use of renewable energy sources.

Despite the fact that, since the early 1990s, both the United Kingdom and Germany have had public policies supportive of bringing renewable energy technologies onto the market, the increased energy capacity generated from renewable resources in the two countries reveals striking differences. In Germany, since 1990 it has been possible to increase the share of energy generation from renewable sources significantly, by 40 per cent (Staiß 2000). In the electricity market, it has been possible to increase the share of renewable sources used for electricity generation to more than 6 per cent of the total electricity generated (Bundesministerium für Umwelt 2000). Related to this, there has been a tremendous increase in the number of wind power installations constructed: Their generation capacity currently approaches a threshold of 9,000 MW. The portion of other renewable energy technologies was also able to be clearly expanded in the course of the 1990s: The portion of biomass in electricity generation was able to be quintupled (from 2,000 $\mathrm{GWh}$ to $10,000 \mathrm{GWh}$ ), and electricity generation from smaller hydro-electric power stations was able to be increased by 1,000 GWh (Staiß 2000). Despite comparable natural pre-conditions for using renewable energy sources in energy generation, ${ }^{4}$ the United Kingdom has not been as successful in increasing the capacity of renewable energy technologies: At the end of 1999, renewable energy sources accounted for only 2.8 per cent of the total electricity generated (Department of Trade and Industry 2000). From the time the policy to bring renewable energy technologies onto the market was broadened, in 1990, until the end of 1999, less than 1,000 MW of generation capacity was installed (Mitchell 2000).

Considering that in comparative policy studies of neo-institutional provenience, federal states are usually perceived as being less capable of initiating innovative reform policies than are unitary states, the different policy outcomes resulting from the introduction of innovative renewable energy technology give rise to some challenging questions. The hypothesis that unitary states have a better problem-solving capacity is often based on the further hypothesis - namely, that due to a lower number of veto points, their governments are able to more efficiently and directly issue public policies aimed at solving the problems at hand. In light of this, the concentration of executive power in one party governments, the predominance of government vis-à-vis the Parliament, the two party system, together with the majority vote system, and, finally, centralised government (Wachendorfer-Schmidt 2001) are regarded as being supportive of the political problemsolving capacity. Against this background, this work aims to examine in more detail the impact of different institutional settings (the federal versus the unitary system of government) on the policy-making supportive of renewable energy generation in the United Kingdom and in Germany.

4 Concerning the preconditions for wind power installations, the United Kingdom has at its disposal even better geographical characteristics than Germany. 
To analyse and explain the differing innovation capability within both countries in reference to such technologies, I basically refer to a combination of two explanatory factors that have influenced the policy development for renewable energy in the respective country: As mentioned before, one concerns the political-administrative system of the country (i.e. the unitary state in the United Kingdom versus the federal state in Germany) and views the modes of sectoral governance as a link between the political-administrative system and the electricity industry. In this context, the analysis of the impact of different political-administrative systems on the innovation capability in one field of utility regulation (i.e. renewable energy generation) will help to compensate for the scarce qualitative research on the repercussions that different state structures have on inducing and implementing the respective policy reforms (Braun 2000).

The other explanatory factor for the differing innovation capability concerns the role of different policy paradigms that dominated the energy policy in the United Kingdom and in Germany when the policies for renewable energies were being made. Analytically, paradigms consist of beliefs, values and techniques shared by members of any community, for example a scientific community or, as in this article, a community defined by the actors dominating the sectoral policy (Bernstein 1976). The 'overarching set of ideas' entailed within the paradigm 'specify how the problems facing [decision-makers] are to be perceived, which goals must be attained through policy and what sorts of techniques can be used to reach those goals' (Hall 1992). Related to this, the energy policies in both countries reveal decisive differences with regard to the prevailing policy paradigms that dominated sectoral policy since the late 1980s. Whereas in the United Kingdom the regulatory challenge to introduce competitive market structures into the formerly monopolistic and nationalised energy market became the hegemonic sectoral policy paradigm already in the late 1980s, in German energy policy the issue of liberalisation gained importance only during the 1990s. As will be elaborated in this article, the different starting points for the liberalisation of the sector added different weight to the prominence of efficiency criteria with regard to the instrumental design of the policy aimed to support renewable energy generation. ${ }^{5}$ Whereas the different starting points of the liberalisation of the sector have already been an object for analysis of other political scientists, ${ }^{6}$ the impacts of such differences on other regulatory

5 The impact of liberalisation policies and belief systems on the different regulatory policies in some European countries has already been examined for the rail sector (Héritier and Knill 2000). Those authors distinguish between the pre-liberalisation and liberalisation stage, which have different repercussions for the reform policy output and structural adjustments in the respective national rail policy. Related to this, the "stage of preliberalisation is defined by the prevailing use of policy instruments which are still clearly of interventionist nature (...)" (Héritier and Knill 2000). While the European liberalisation policy for the electricity market was not started before 1996, I will nevertheless argue that different starting points for liberalisation policies in the United Kingdom (1989) and Germany (1998) were of pivotal significance for the choice of regulatory policies supporting renewable energy technologies.

6 In his comprehensive analysis for different liberalisation policies concerning the energy market in the United Kingdom and in Germany, one of Eisings's (2000) explanatory statements for the later liberalisation in Germany refers to the particularities of the German market structure: A comparatively higher number of utilities operating on the local, regional and transmission system operators' level was closely linked to and controlled by the respective German statutory corporations. Especially the states and local authorities had strong political influence on the corporate governance of the utilities. In his argumentation, the larger complexity of the market structure together with higher requirements for political consensus due to the federal structure of the German state had prevented an earlier breakthrough of the liberalisation paradigm in this country. Especially the interest groups representing the local utilities resisted strongly against plans for opening the national en- 
policies like enviromental regulations for renewable energy generation have not been examined more in detail until now. This article is supposed to remedy this lack of research: It will analyse and explain the different outcomes of renewable energy policy in both countries by referring to the impacts of different political-administrative systems and the various prominence attached to the issue of sectoral liberalisation. Because the energy sector in the United Kingdom was liberalized earlier, the market creation policies and market correction policies there were clearly interdependent. Therefore, the market correction policy of introducing renewable energy technologies in competitive markets is a descriptive case for analysing the relation between both logics, which 'cannot be clearly separated, but rather coexist and may conflict' (Prosser 1999).

To examine the different degree of innovation capability in the United Kingdom and Germany in reference to the example of renewable energy technologies, this article is divided into two parts. In the first part I will analyse the commencements of the first wider public policies in both countries that aimed at promoting renewable energy technologies. This part will cover the time period from 1985 until 1997 and take into account the impacts of domestic technology policies on the development of further policies aimed at bringing renewable energy technologies onto the respective market. I will argue that the technology policies differed significantly due to the contrasting characteristics of the respective political-administrative systems and to the differing modes of sectoral governance that linked the political-administrative system and the electricity industry. The outcomes of the respective technology policies are perceived as crucial since they affected which practices and policies the policy-makers at the time perceived as the best to introduce these innovative technologies to the market. Then I will describe the impacts of the technology policy on the development of the subsequent renewable energy policy, which aimed to guarantee the construction and operation of renewable energy facilities a secure place under competitive conditions. Furthermore, I will examine the implementation of the respective renewable energy policies from the early 1990s until early 2001. To account for the performance of each renewable energy policy, I will once again refer to my combination of two explanatory factors, i.e. to the differing emphasis of the efficiency criteria in sectoral policy (due to the different starting points of the sectoral liberalisation) and the impacts of the different politicaladministrative systems on implementation. Since the renewable energy policies in both countries follow different approaches (price versus quota regulations), this study will also contribute to the current debate on the effectiveness of the respective regulatory approach to promoting renewable energy technologies (Espey 2001).

The second part of the article covers recent reforms in the renewable energy policies in both countries. Again, I will examine these reforms in reference to my combination of the two ex-

ergy market to competition. As a result, the complexity of interests involved for the policy-making in German energy policy provided for the precondition that the existing policy paradigm in that time (i.e. energy sector as natural monopoly) could be maintained longer than in the United Kingdom (Eising 2000, 268-284). In sum, the unitary political-administrative system of the United Kingdom made this country more prone to fundamental change than the federal political-administrative system of Germany. In the latter, the country features of a federal state, in combination with its 'semi-souvereign structure' (Katzenstein 1987), made strong requirements for achieving consensus between the different political actors and levels for the implementation of more fundamental reforms. 
planatory factors. In the United Kingdom, since 1997, the new Labour Government has partly challenged the hegemony of the dominating sectoral policy paradigm of pure 'liberalisation', and this has resulted in a general reform of the regulatory policy in the utilities sector. One of the reasons for this challenge is the increasing significance of sustainability issues. Climate change issues have become more widely diffused in the sectoral policies of both countries since the conclusion of the Kyoto-Protocol in $1997 .{ }^{7}$ Whereas the regulatory reform for the utilities in the United Kingdom implied significant reforms in the government's renewable energy policy, the liberalisation of the German electricity sector in 1998 forced the German government to further adapt their existing policy, too. It increasingly confronts policy-makers with the difficulty of bringing these innovative technologies onto the market without jeopardising competition. Nevertheless, because of having more successfully implemented the former approach, the German renewable energy policy has greater continuity. The table on the next page provides for a short overview of the structure of this article.

In the aftermath of the Protocol, the EU member states negotiated a burden sharing agreement where each member state agreed on specific reduction targets for greenhouse gas emissions, to contribute to the general 8 per cent reduction target that the European Union confirmed in the Protocol. After a first revision of a first burden-sharing agreement in March 1997, new reduction targets were defined in June 1998. In a second agreement, the United Kingdom comitted to reducing greenhouse gas emissions by 25 pecent from 20082012. Germany wanted a reduction target of 21 percent (Oberthür and Ott 1999). In this regard increasing the use of renewable energy technologies is a decisive strategy for achieving these emission reduction targets of greenhouse gases. In order to complying with them, the United Kingdom has defined in its climate change programme so as to source 10 per cent of electricity from renewable sources by 2010 (Department of the Environment, Transport and the Regions 2000). The target of the Federal government in Germany is to double the proportion of renewable energy sources compared with current levels by the same year (which means achieving a level of 12.5 per cent in total electricity generation) (Bundesministerium für Umwelt, Naturschutz und Reaktorsicherheit 2000, 2002). 
Table 1: A Comparison of Renewable Energy Policy in the United Kingdom and in Germany

\begin{tabular}{|c|c|c|}
\hline & $\begin{array}{c}\text { United Kingdom } \\
\text { Unitary political-administrative system } \\
\text { in combination with } \\
\text { early sectoral liberalisation }\end{array}$ & $\begin{array}{l}\text { Germany } \\
\text { Federal political-administrative system } \\
\text { in combination with } \\
\text { late sectoral liberalisation }\end{array}$ \\
\hline $1985-1990$ & $\begin{array}{l}\text { Technology policy for renewable energy } \\
\text { generation in a unitary state and a central- } \\
\text { ised electricity market } \rightarrow \text { innovation }\end{array}$ & $\begin{array}{l}\text { Technology policy for renewable energy } \\
\text { generation in a federal state and a decen- } \\
\text { tralised market } \rightarrow \text { innovation }\end{array}$ \\
\hline $1990-1997$ & $\begin{array}{l}\text { Policy development and implementation to } \\
\text { bringing and spreading renewable energy } \\
\text { technologies onto the liberalised market: the } \\
\text { case of quota regulation }\end{array}$ & $\begin{array}{l}\text { Policy development and implementation to } \\
\text { bringing and spreading renewable energy } \\
\text { technologies onto the monopolistic market: } \\
\text { the case of price regulation }\end{array}$ \\
\hline $1997-2001$ & $\begin{array}{l}\text { Reform and new orientation of existing pol- } \\
\text { icy due to changing contextual factors: } \\
\text { - Change in government } \\
\text { - New reforms for the electricity market } \\
\text { - Kyoto-Protocol } \\
\text { - Forecasts of changing fossil-fuel } \\
\text { resources } \\
\text { - Unsuccessful implementation of former } \\
\text { renewable energy policy }\end{array}$ & $\begin{array}{l}\text { Continuing development of existing policy } \\
\text { due to changing contextual factors: } \\
\text { - Change in government } \\
\text { - Liberalisation of the German electricity } \\
\text { market } \\
\text { - Extension and adaptation of existing } \\
\text { policy due to increasing implementation } \\
\text { problems of the former policy }\end{array}$ \\
\hline
\end{tabular}

\section{The Commencements of Renewable Energy Policies in the United Kingdom and in Germany}

Due to the fact that renewable energy technologies represent innovative and in most cases not yet competitive generation installations - because of their higher generation costs in comparison to established generation facilities operating on the basis of fossil fuels, e.g. coal, gas, etc. - it is thought necessary to improve their technological operation to ensure their competitiveness in liberalised markets. Consequentially, public technology policies and respective subsidies are decisive for providing for the required technological improvements, which lower their generation costs and thus increase the efficiency of energy generation. In this context I will argue that different characteristics of the political-administrative system (the unitary state in the United Kingdom, the federal state in Germany), in combination with different policy paradigms that dominated the sectoral policy in the late 1980s, had important repercussions on the respective technology policies. The performance of the respective technology policies is thought to be crucial to the perceived feasibility of renewable energy facilities an had decisive impacts on the development and establishment of subsequent policies targeted at extending the share of renewable energy technologies onto the respective electricity market. For that reason, I will examine the impacts of different technology policies on the policy development of subsequent supportive poli- 
cies for renewable energy generation. Accordingly, the development of the first wider renewable energy policy in the United Kingdom was influenced by the outcomes of the British technology policy and the prevailing policy targets, i.e. sectoral privatisation and liberalisation. In Germany, the features of a federal political-administrative system resulted in a technology policy differing from the one in the United Kingdom, one implying decisive impacts on the further development of a wider policy aimed at supporting renewable energy.

In a next step I will illustrate the subsequent policy development for renewable energy generation, which should guarantee developed renewable energy technologies a secure place in the respective electricity market. In both countries these wider renewable energy policies were started in the early 1990s. After that, I will analyse the implementation of them. In accordance with the initial propositions, the different results of the implementation will be attributed to the main factors earlier proposed as explaining the difference in the capacity building of renewable energy generation in these countries. On the one hand, this differing capacity is due to the differing emphasis that each country, given the predominance of different policy paradigms, puts on efficiency-criteria in sectoral policy-making; on the other hand, it is due to the impact of features of the political-administrative system.

\subsection{The Commencement of a Renewable Energy Policy in the United Kingdom}

In the following I will examine the sectoral coordination and governance of the electricity utilities in the United Kingdom from the mid-1980s to the early 1990s, when this industry underwent a fundamental transition from a monopolistic industry to a privatised one. In this connection I will analyse the impacts of the specific modes of sectoral governance, which are understood as patterns of coordination between the unitary UK government and the industry on the national technology policy for renewable energy generation. In the United Kingdom, these were characterised by centralised patterns, which had decisive impact on the outcomes of the technology policy targeted to develop decentrally operating renewable energy facilities. The outcomes of the national technology policy are perceived to be crucial for the development of a wider market introduction policy for renewable energy generation in the proximate period.

\subsubsection{The Sectoral Governance of the Electricity Supply Industry Before Liberalisation and the Impact of that Governance on Technology Policy for Renewable Energy Generation}

When the electricity industry in the United Kingdom was a nationalised and monopolistic sector, the role of the Central Electricity Generating Board (CEGB) in the national energy policy was dominant. The CEGB was the central authority co-ordinating the electricity supply industry (Ledger and Sallis 1995). In carrying out this function, this board was responsible for the construction and operation of all the power stations and for the transmission of electricity via the national grid to 14 regional electricity companies, the latter then being responsible for the distribution to the final customers. The dominance of the former CEGB in the sector is very clear with 
regard to another issue: it supplied 95 per cent of the power requirements in England and Wales. An Electricity Council was to take over coordination functions for the industry-wide management of finance, taxation, industrial relations and - an area of specific importance for this article - research and development policies. But in fact, "the Electricity Council had no control over the CEGB or the Area Boards (Regional Electricity Companies), and the latter had little influence over the CEGB" (Chesshire 1996). Because it had been a nationalised industry, the structure of the electricity industry was highly integrated and centralised.

Facing a nationalised industry until the sectoral liberalisation in 1989, the British government approached the electricity industry with a very restrained style of intervention. "Governmental action on the whole was characterised by limited control over and an absence of co-ordination between the individual corporations" (Burgi 1985). The "politics of the nationalised energy industries were characterised by a tendency for each energy form to develop its own policy network and operating procedures" (Taylor 1992). "This meant that each energy form's network was closed to penetration by others, and horizontal linkages between networks tended to be minimal (...). As horizontal linkages were weak or non-existent, the government's room for manoeuvre in the field of energy policy was curtailed. It would have required a dramatic and sustained effort of governmental will to impose an overall policy on these powerful vertical policy networks" (Taylor 1996). Moreover, the electricity and power supply of the country relied heavily on coal. For example, British Coal had a guaranteed market for a large part of its output (75 mt) through a joint agreement with the CEGB, dating from 1979.

The dominant position of the CEGB implied that most decisions concerning the input of resources for energy generation were solely determined by this central planning organisation. Generally, this board had "immense (effectively monopsony) power over its equipment suppliers, with its purchasing policy determining which technologies were developed and which companies survived" (Thomas 1997). The narrowly coupled modes of governance linking the CEGB and the traditional branches of the fossil and nuclear energy industries scarcely allowed other technologies to diffuse into the system, especially those characterised by decentralised generation such as renewable energy technologies. For that reason, the governance structure linking the CEGB and the different energy industries did not provide a favourable opportunity structure for reforms that would integrate more sustainable and decentralised forms of energy generation. In the following, this will be illustrated in reference to the technology policy for the development of renewable energy generation.

From the mid-1970s the UK government supported renewable energy technologies with research and development programmes. In this time period, strategical decisions regarding the directions of research and development programmes were clearly dominated by the CEGB. The "CEGB dictated the pace of change in generating technology" (Chesshire 1996). The centralised governance structure of the British energy industry tended to give generous support to generation technologies with features resembling those of the sectoral structure: namely centralised and largescale generation technologies. For example, during the 1970s and 1980s fossil and nuclear plants 
were rapidly upscaled. ${ }^{8}$ Another reason for the single-oriented research and development strategy, which promoted mostly large-scale generation technologies, was that "for too long, and with Government support, in the 1970s the CEGB favoured the notionally competitive approach of supporting two major British suppliers of key items of conventional plant" (Chesshire 1996). This bipoly structure of public support policies, together with the CEGB's commitment to nuclear power, led to a one-dimensional concentration in the research and development efforts. When Government and CEGB adopted the Pressurised Water Reactor (PWR) in 1979, it spent large sums to become thoroughly familiar with this technology and to adapt it to UK safety requirements.

The CEGB was frequently criticised for failing to commit sufficient resources to renewable energy technologies. And even within the government's renewable energy programme, different inconsistencies prevented it from committing to a more pro-active approach. These inconsistencies concern "large changes in government priorities for supporting the different types of renewables over the past twenty years which, although no doubt unavoidable to some extent, have reduced the continuity of the development effort" (Mitchell 1996). ${ }^{9}$ Another problem was that investments were wrongly focused: "The major proportion of the total R\&D expenditure was on technologies, which have, for all intents and purposes, been curtailed (wave and geothermal), or changed tracks, such as the wind programme. With a view to developing large-scale turbines, a quarter of the wind programme resources were spent on the 3 MW Orkney wind machine. This turbine is to be dismantled and the wind programme has now [been] radically altered to investigate smaller-scale turbines" (Mitchell 1996). Currently (in 2000), smaller-scale wind turbines with a generation capacity of between 1.5 MW and 2.5 MW are the biggest mass-produced installations that can still be operated efficiently (Pürtul 2002).

The influence of the CEGB on the development and research programmes "led to a few projects and programmes receiving a large share of the total budget. The CEGB was mostly interested in developments capable of bulk energy generation such as large wind turbines, tidal power and HDR. Such R\&D programmes were expansive and one third of the total available funds were consumed by the Svern and Mersey Barrages, large and vertical-axis wind turbines and HDR, none of which have come to fruition" (Mitchell 1996). Therefore, the research and development programme of the CEGB supported the wrong renewable energy technologies (projects of overly large dimensions) to the detriment of those that later could have been successfully established in the UK's electricity market (smaller wind power installations, which by and large are currently contributing to the big increase in the renewable energy capacity in Germany).

Reasons for this were "fears about increasing difficulty to obtain planning consents for new sites and thus choice for larger units to conserve available sites; and general confidence among power plant engineers in various countries that generation would be subject to increasing scale economies in set sizes up to $1000 \mathrm{MW}$ or even 1500 MW" (Chesshire 1996).

9 Whereas in $197860 \%$ of programme expenditure was given to wave power, this share fell to $10 \%$ in 1991 due to its lack of success. On the other hand, in the promotion of wind energy the percentage given to support it increased gradually. 
In conclusion, the pre-dominance of the CEGB's influence on the monolithic structure of the energy industry had negative impacts on the directions of the research and development programmes: By supporting the wrong technologies, it prevented the breakthrough of ideas for decentralised concepts of electricity generation and supply. Generally, the monopoly position of the CEGB "on the generation side encouraged large-scale generation facilities, with little interest in promoting small-scale options such as CHP (i.e. combined heat and power, A.S.) and renewables. The structure was particularly suited to the expansion of nuclear power" (Collier 1994). Hence, the neo-corporatist mode of governance linking the CEGB and the incumbent energy industries prevented the sector from re-orienting itself towards more decentralised generation technologies. Additionally, in the course of the 1980s another policy paradigm increasingly dominated the attention of the policy-makers in British energy policy: the challenge of privatisation and liberalisation. Against the background of rather unsuccessful experiences in developing renewable energy technologies, it seemed sensible to focus on market-based policies aimed at bringing only the most developed and competitive renewable energy technologies onto the market. The development and contents of the first wider policy for renewable energy generation in the United Kingdom will be described in the next section.

\subsubsection{The Policy-Development of a First Wider Renewable Energy Policy in the United Kingdom: The Non-Fossil-Fuel Obligation}

When the United Kingdom began expanding its renewable energy policy, its energy policy was concerned with the most extensive privatisation and liberalisation enterprise that had ever been undertaken in British history, i.e. that of the national electricity supply industry (in relation to telecommunication and rail). ${ }^{10}$ Accordingly, at that time energy policy 'was driven absolutely by its liberalisation, everything else was simply attributed to it' (DTI, Nov. 2001). The transition from a formerly nationalised and monopolistic industry to a privatised and competitive one was clearly dominated by the pivotal challenge to secure the supply of electricity ('to keep the lights on'), and to do so at reasonable costs.

However, the early privatisation and liberalisation of the electricity sector did not imply that a policy for renewable energy did not exist. The first initiatives for expanding renewable energy started in 1988, when the British Government presented plans for the development and exploitation of renewable energy sources. These early plans were to be attained by extending the scope of an already existing policy to the area of renewable energies, i.e. the Non-Fossil-FuelObligation (NFFO) for nuclear power generation. ${ }^{11}$ To ensure the competitiveness of nuclear

10 In relation to the liberalisation and privatisation policies in other sectors, the liberalisation of the electricity supply industry (ESI) was the 'biggest and most radical project in the extensive UK privatisation programme': It was the only major public utility privatisation which involved significant restructuring in order to promote competition in generation, and in retail electricity supply, and in order to separate transmission from generation. With a book value of assets of at least $£ 42$ billion, on a current cost basis, the ESI was the 'jewel of the whole privatisation programme' (Surrey 1996).

11 Initially, the NFFO was only to secure a place for the British nuclear power industry in the new competitive setting. Related to this, the liberalisation of the electricity sector in 1989 led to increasingly shorter depreciation periods, which meant a greater risk to long-term investment technologies, such as nuclear power. As a consequence, the costs for nuclear power generation exploded during the privatisation process: while in 1988 
power, the NFFO required the Regional Electricity Companies (REC, i.e. the companies distributing and supplying electricity to the final customers) to buy a certain amount of electricity generated from non-fossil fuel sources. In other words, NFFO guaranteed the purchase of electricity from nuclear and later from renewable sources at premium price conditions. The NFFO subsidy scheme was financed by the fossil-fuel-levy (FFL), which was paid by the final consumer. It allowed the firm that operated the nuclear power stations (i.e. British Energy) to sign contracts at above pool prices ${ }^{12}$ and to receive a steady (and very substantial) flow of revenue for their future decommissioning and fuel reprocessing liabilities. In this context, the easiest way to do something quick and straightforward (by bypassing the demands of a long legislative process) for renewable energy technologies (DTI, November 2001) was to shift a share of the NFFO-budget from nuclear power to the area of renewable energy sources. Similarly to the nuclear obligation, the renewables obligation required that the RECs secure a specified capacity each year from renewable sources (Ross 2000). Hence, the NFFO - which was later to become the pivotal policy instrument to support renewable energy sources - "developed out of the need to find a means of supporting nuclear power, once it was realized that the nuclear portion of the electricity supply industry could not be privatised in 1989" (Mitchell 1996).

In the early 1990s only a very small amount from the total NFFO budget was used to support renewable energy generation: Until 1996 more than 90\% of the revenues subsidised energy generation from nuclear power. From the end of 1996 to March 1997 a significant shift in the use of the FFL occurred: The share of revenues from this levy that were used to support renewable energy generation was increased from $10 \%$ to $23 \%$. By the end of 1998 this portion was further increased to $49 \%$, but there was a tremendous downturn in the total revenues of this levy in the same time period. Interestingly enough, one reason for the increasing use of revenues for renewable energy generation was the European competition policy. The European Commission threatened to deny approval of the FFL for competitive reasons. In terms of European competition law, an important subsidy like the fossil fuel levy is only able to be justified for specific reasons, e.g. if its revenues are used to the specific benefit of environmental objectives. One reason for the

the operation costs for a specific type of pressurised water reactor (Hinkley Point C) were estimated by the Central Electricity Generation Boards to be approximately $2.24 \mathrm{p} / \mathrm{kWh}$, only one year later, the successor company of the CEGB responsible for the nuclear power industry (i.e. British Energy) calculated the costs on a completely different basis, leading to figures of around $6.25 \mathrm{p} / \mathrm{kWh}$. Consequently, British Energy doubled the necessary rate for payment of interest and halved the time for depreciation to 20 years.

12 The Electricity Pool that was established with the market liberalisation in 1990 was a very complex trading mechanism for the generators. It was expected to establish a wholesale market for electricity generation and through that introduce competition in that part of the market. It was an open commodity market where any generator exporting more than $50 \mathrm{MW}$ into the system (i.e. the National Grid) was required to hold a generation license and obliged to trade its output within. All generators that wanted to operate their plant had to declare their availability of generation capacity for the following day announcing the price at which they would be prepared to operate for each and every half hour. The National Grid then called the respective generators in ascending order of their bidded price. The most expensive unit used to establish the System Marginal Price (SMP), which all other generators received for that half hour (Electricity Association 1999, Thomas 1996). During the first years of liberalisation, the establishment of competition in the electricity generation market proved to be a very difficult challenge. Initially, the generation market was characterised by an oligopolistic structure comprised of only three generators: National Power, PowerGen and British Energy (the latter was responsible for the national nuclear power industry). These three companies were the successors arising from the former CEGB, which was abolished with the initiation of the liberalisation programme. 
increasing utilisation of the fossil fuel levy to support renewable energy technologies was therefore to avoid the threat of forced changes to the European Competition Law. The table below illustrates the change in the use of revenues from the FFL as it transferred them from nuclear power to renewable energy resources from 1990 to 1997.

Table 2: The Fossil-Fuel-Levy (FFL) and its Use For Nuclear Generation and Renewable Generation

\begin{tabular}{|c|c|c|c|c|}
\hline Year & $\begin{array}{l}\text { Total raised } \\
\quad(£ \mathrm{~m})\end{array}$ & $\begin{array}{l}\text { Portion for } \\
\text { Nuclear Genera- } \\
\text { tion }(£ m)\end{array}$ & $\begin{array}{l}\text { Portion for } \\
\text { Renewables } \\
\text { (£m) }\end{array}$ & $\%$ \\
\hline $1990-91$ & 1.175 & 1.175 & 0 & 0 \\
\hline $1991-92$ & 1.324 & 1.311 & 13 & 1 \\
\hline 1992-93 & 1.348 & 1.322 & 26 & 2 \\
\hline 1993-94 & 1.234 & 1.166 & 68 & 5.5 \\
\hline 1994-95 & 1.205 & 1.109 & 96 & 8 \\
\hline $1995-96$ & 1.105 & 1.010 & 95 & 8.6 \\
\hline 1996-97 & 844 & 732.5 & 111.5 & 13.2 \\
\hline $\begin{array}{l}\text { April } 1996- \\
\text { October } 1996\end{array}$ & 633 & 570 & 63 & 10 \\
\hline $\begin{array}{l}\text { November } 1996 \text { - } \\
\text { March } 1997\end{array}$ & 211 & 162.5 & 48.5 & 23 \\
\hline 1997-98 & 279 & 142.3 & 136.7 & 49 \\
\hline
\end{tabular}

Source: OFFER Press Releases, Annual

To implement NFFO, initially the former Department of Energy (DoE), and after its abolition in 1992, the Department of Trade and Industry (DTI), as the co-ordinating Ministry for the regulation of the electricity generation industry, had to define the renewable energy capacity that was to be eligible for funding from the FFL. The regulation of the renewable energy capacity was therefore based on a principle of quota regulation, which implied strong central government involvement in defining and implementing renewable energy projects. Hence, the UK renewable energy policy was initiated with a top-down-approach by the public administration (here the DTI, formerly the DoE). The strong role of the central government is not only indicated by its power to define the eligible capacity of renewable energy generation for a specific time period, but also by its power to determine the capacities of different renewable energy technologies (socalled technology bands) that were to be promoted. Therefore, NFFO was called a 'banded obligation': It forced the government of the UK 'to pick winners', i.e. to decide over the eligibility of single renewable energy technologies. In other words, government had the final say on the technologies and the respective funding that they were to be eligible for. 
In 1990 government decided to commission $1,000 \mathrm{MW}_{\mathrm{DNC}}{ }^{13}$ of new electricity capacity, which was to be generated by renewable sources until the year 2000. Shortly after this, the amount was increased to $1,500 \mathrm{MW}_{\mathrm{DNC}}$ (roughly $3 \%$ of electricity supply by 2000). This objective was to be achieved through different tendering procedures, wherein different renewable energy projects from one technology were to compete to participate in the NFFO support schemes. The way this support policy operated clearly shows the strong influence of the efficiency-orientation in the policy to guarantee renewable energy technologies a place in the competitive market. This efficiency orientation points to the dominance of liberalisation issues in the energy policy of the UK at that time. In accordance with this, operators of renewable energy installations who wanted to participate in the scheme had to bid for the tendered amounts of eligible capacity, first, by determining the quantity of energy that they would feed into the grid. Second, they had to define a price per $\mathrm{kWh}$ for the produced electricity. After this bidding procedure, the DTI ranked the operators according to the offered prices and capacities. The highest price of the last bidder who was able to participate with his offer and replenished the tendered amount determined the price for all other bidders. As a consequence of this system, the operators could not count on fixed prices for their generated output before the tendering procedure was finalised. Only those companies that successfully bid to participate received reimbursement for the difference between the defined premium price and the pool-selling price. As such, only the cheapest bidders within one single technology band were awarded contracts and were eligible for support (only since the tendering procedure of NFFO-2, the Renewables Obligation was technology-oriented, i.e. banded, which meant that wind projects only competed against other wind projects, etc.). Altogether there were five tendering procedures, generating an energy capacity of about $3 \mathrm{GWs}$, which were awarded contracts until the year 2000 (see table 3). NFFO 1 and NFFO 2 contracts lasted until the end of 1998, while NFFO 3 to NFFO 5 contracts were for 15 years, following a maximum 5 year development period (Mitchell 2000).

Given the strong efficiency-orientation of the support policy for renewable energy generation, one might ask why the fundamental transition towards liberalisation has not been interpreted as a favourable time to start more active and progressive reforms directed at renewable energy generation. However, given the existence of indigenous fossil resources, like coal, oil and gas, which have been used for decades, alternative sources for energy generation - such as renewable sources - were never seen as particularly necessary (DTI, November 2001). Specifically, given the rather unsuccessful public research and development policies for these generation technologies, under the new competitive market conditions, the policy-makers did not perceive them to be a realistic alternative. In this regard, the outcomes of the technology policies negatively affected the political perception in the relevant ministries: many renewable sources of energy were neither viewed as practicable nor as competitively feasible in the newly liberalised market.

13 MWDNC = Mega Watt Declared Net Capacity where DNC is the equivalent of the base load plant that would produce the same average annual energy output. 


\subsubsection{The Implementation of the Non-Fossil-Fuel-Obligation}

The following section scrutinizes NFFO's policy implementation. After illustrating the implementation results, it explains the policy outcomes, referring to the combination of my two explanatory factors that were already used to account for the policy development within NFFO. For an initial overview, the table below contains data on the implementation of NFFO-projects in the respective rounds until 2000.

Table 3: Status of NFFO 1-5

\begin{tabular}{|l|c|c|c|c|c|c|c|c|c|c|}
\hline & \multicolumn{2}{|c|}{$\begin{array}{c}\text { Projects } \\
\text { contracted }\end{array}$} & \multicolumn{2}{c|}{$\begin{array}{c}\text { Projects } \\
\text { generating }\end{array}$} & \multicolumn{2}{c|}{$\begin{array}{c}\text { Projects } \\
\text { terminated }\end{array}$} & \multicolumn{2}{c|}{$\begin{array}{c}\text { Projects to be } \\
\text { commissioned }\end{array}$} & \multicolumn{2}{c|}{$\begin{array}{c}\text { Completion } \\
\text { Rates (\%) }\end{array}$} \\
\hline & Number & MW & Number & MW & Number & MW & Number & MW & Number & MW \\
\hline NFFO 1 & 75 & 152.12 & 61 & 144.53 & 14 & 7.58 & 0 & 0 & 81 & 93 \\
\hline NFFO 2 & 122 & 472.23 & 82 & 173.73 & 40 & 298.49 & 0 & 0 & 67 & 37 \\
\hline NFFO 3 & 141 & 626.91 & 58 & 191.4 & 2 & 1.9 & 83 & 460.99 & 40 & 26 \\
\hline NFFO 4 & 195 & 842.72 & 10 & 18.46 & 0 & 0 & 187 & 828.96 & 4 & 2 \\
\hline NFFO 5 & 261 & 1177 & 0 & 0 & 0 & 0 & 0 & 0 & 0 & 0 \\
\hline Total & 794 & 3270.98 & 211 & 528.4 & 56 & 307.97 & 270 & 1289.95 & 192 & 158 \\
\hline
\end{tabular}

Source: Mitchell 2000

Whereas NFFO seems to have "succeeded in bringing the prices for renewable energy generation down", ${ }^{14}$ in later rounds it increasingly failed to realise the respective projects as stipulated in the NFFO contracts (DTI, November 2001). Therefore, the key weakness of the NFFO policy is that it led to an increasing gap between the contracted and commissioned capacity in the different NFFO rounds. The following table indicates the decreasing commissioning rates for contracted renewable energy projects:

Table 4: Commissioned Capacity by NFFO round (at 31/12/2000)

\begin{tabular}{|c|c|c|c|c|c|}
\hline & NFFO 1 (1990) & NFFO 2 (1991) & NFFO 3 (1997) & NFFO 4 (1997) & NFFO (1998) \\
\hline $\begin{array}{c}\text { Commissioned } \\
\text { (MW) }\end{array}$ & 69 & 100 & 204 & 140 & 55 \\
\hline $\begin{array}{c}\text { Commissioned } \\
(\%)\end{array}$ & $95 \%$ & $71 \%$ & $55 \%$ & $24 \%$ & $8 \%$ \\
\hline
\end{tabular}

Source: Cleirigh 2001

On the one hand, the reasons for the steadily worsening implementation of the NFFO policy can be found in characteristics of the political-administrative system. In this regard, the centralised

14 The following price reductions for energy produced from renewable sources could be achieved in several NFFO-rounds: NFFO 1 (1990): 7.51 p/kWh, NFFO 2 (1991): 8.78 p/kWh, NFFO 3 (1994): 4.84 p/kWh, NFFO 4 (1997): 3.59 p/kWh, NFFO 5 (1998): $2.71 \mathrm{p} / \mathrm{kWh}$. Prices are indexed to 1998/99 price levels and weighted according to the projected output from each contract. However, two points remain very controversial: To what extent can these price reductions really be attributed to the existing NFFO-policy? And do they reflect adequately real cost reductions in these generation technologies? 
features of the national planning system significantly restricted the attempts to implement decentralised renewable energy projects for electricity generation. Furthermore, the focus on competition, which could be attributed to the dominating efficiency orientation of the sectoral policy when NFFO was issued, strongly constrained the efforts to implement renewable energy projects (Cleirigh 2001).

The need for timely consent to planning, in accordance with the requirements laid down in the NFFO contracts, is predominantly a problem for wind energy. ${ }^{15}$ This technology band, which experienced tremendous capacity building in Germany, faces especially serious resistance from the national planning system. Since renewable energy projects must be implemented on the local level, political support from that level is necessary to bring them about. Whereas the UK government defines the national planning guidelines, the local planning authorities determine the weight they place on different planning concerns. Reinforced by the existence of campaigns opposed to renewable energy projects (especially from landscape organisations against wind power), national and local government have different motivations for awarding planning commissions. Accordingly, local planners and planning inspectors emphasize local environmental factors more than they emphasize national renewable energy targets (Cleirigh 2001). As a result of this lack of planning capacity on the regional and local level and the lack of political consciousness for sustainable energy generation on these levels, the ongoing reform of the national planning system currently aims to delegate more regulatory responsibilities to this level of governance (Thomson 2001; Department for Transport, Local Government and the Regions 2002). Consequentially, a recent report of the Performance and Innovation Unit stressed the necessity of giving renewable energy generation greater prominence in the regional and local planning system. Regional planning bodies should place 'greater prominence on energy issues in regional planning guidance' (Performance and Innovation Unit 2002). A first step towards achieving this target was agreed upon: All Government Offices of the Regions in England and Wales were to carry out regional renewable energy studies in order to assess the potential for renewable energy developments within their respective regions. ${ }^{16}$ The results of these studies are currently being assessed by DTI (Department of Trade and Industry) and DTLR (Department of Transport, Local Government and the Regions). The report also recommended assigning a regulatory duty to

15 According to the old NFFO-regulation, the person who received the bankable contract under NFFO obtained the public subsidy only under the premise that he realises the project at the location and in the dimension suggested in the tendering procedure. Until recently, he was strictly bound to the instructions he had delivered in this procedure and was not given any flexibility. Considering the precisely defined time period in these contracts, which scheduled the planning interval for which the projects would be eligible, the increasing delays to commissioning the respective installations due to unavailable planning consent resulted in increasing the withdrawal rates of operators from these contracts. Recent reforms on NFFO aim to achieve a more flexible handling of the NFFO-instrument (so-called portability of contracts, i.e. that operators are now allowed to move their project to another location if planning consent at the proposed location is difficult to obtain) and hence to guarantee that the awarded contracts, which until now have not been terminated, are better implemented.

16 Interestingly enough, the establishment of the Government Offices for the Regions by the Conservative Government in 1994 is interpreted as initial move of the United Kingdom towards a more decentralised and regionalised state structure. The regional bodies were set up in light of the European Commission's pressure to set up a regional tier and a regional programme as a framework for the implementation of EU Structural Funds (Isherwood 2002, Newman 2002). 
regional development agencies to set regional targets for renewable energy production in the sustainable development frameworks for their regions. Furthermore, greater emphasis is to be placed on pro-active planning for energy developments at a sub-regional level. As will be elaborated later, the federal system of government in Germany was much more favourable to renewable energy interests since it, early on, provided the federal states and the local community with legislative powers to adapt their respective planning system to the new challenges of sustainable energy generation. In this regard, the rather centralised and unitary characteristics of the political-administrative system in the United Kingdom seems to have hindered local policies (especially building and planning laws) from adapting to the requirements of decentralised and sustainable energy generation earlier.

But it was not only the restrictions of the national planning system that prevented renewable energy policy from being implemented better in the United Kingdom. Another serious hindrance, maybe the most serious one, consisted in the competitive nature of this instrument, which did not result in a pricing mechanism that reflected the real costs for generating electricity from renewable sources. The bidding system is charged with having caused strategic bidding behaviour by the renewable energy developers: It is supposed that their bids for the NFFO competitions were below the real costs of production. From an individual perspective, such bidding behaviour from single developers must be assessed as purely rational: because the contract was for a future project (since NFFO 3 the generation facilities were planned to begin operating five years after the conclusion of the NFFO contract) and expected further technological development would be likely to cut costs, developers calculated the production costs of the respective technology on a decreasing basis. Furthermore, developers generally seemed to have underestimated production costs when putting together their bids, especially financing and planning approval costs. Since there were no substantial penalties for not commissioning projects, developers did not take account of them when production costs did not fall to the required level. As a result, increasing problems in financing and planning ensued (Cleirigh 2001). All this points to hindrances to a market-based approach to introducing innovative technologies onto markets when there is 'bounded rationality' or 'uncertainty' about the future implementation and operation costs. Since most of renewable energy technologies are still being technologically developed, the costs for generating energy from them are continuously decreasing. Consequently, creating a pricing mechanism that adequately reflects the development of real future costs has proven to be an inexpugnable barrier to the more successful implementation of the NFFO policy.

Finally, aspects of the NFFO process itself are supposed to have hampered the implementation of the UK renewable energy policy. First of all, the irregular timing of NFFO rounds contributed to the gap between the contracted and commissioned capacity. The stop-start nature of deployment under NFFO is thought to have "hindered the creation of a stable, continuous demand for components. This probably hampered the development of a UK based manufacturing industry for capital goods and components" (Cleirigh 2001). Some developers of renewable energy projects thus "indicated that the 4-year gap between NFFO 5 and the introduction of the RO was (and still is) too long, hindering progress in this period" (Cleirigh 2001). 
In conclusion, the analysis of the design of the NFFO-policy has shown the strong impact of the policy paradigm that dominated sectoral policy when this policy instrument was developed, i.e. the strong belief in the positive effects of liberalisation on social and individual welfare. The focus on efficiency criteria was tightly anchored within the central government, and due to the unitary structure of UK government, it could hardly be challenged by other political authorities. However, the analysis of the implementation of the NFFO policy has brought to light the limitations of applying the competition principle to the political challenge of introducing innovative technologies. Besides illustrating the role of the technology policy in renewable energy generation, the analysis of the implementation of the renewable energy policy has also illustrated the impact of the political-administrative system. Related to this, the lack of regulatory competencies and the weaker awareness, at the subsidiary political levels (local and regional levels), of the relevance of renewable energy generation worsened the chances for successfully implementing this centrally issued policy. In reference to the example of the federal system of German government, I will subsequently discuss the positive influence of this political-administrative system, in combination with the late sectoral liberalisation, on the development and implementation of the renewable energy policy.

\subsection{The Commencement of a Renewable Energy Policy in Germany}

The development of the renewable energy policy in Germany differs from that in the United Kingdom in two main respects: On the one hand, at the end of the 1980s and early 1990s the electricity industry was not being radically privatised and liberalized. Consequently, the development of the German renewable energy policy was less oriented by efficiency criteria towards achieving a competitively priced renewable energy generation industry. On the other hand, it was marked by the federal state structure and the features of a much more pluralist industry structure. In the following I will elaborate the favourable impact of the federal political-administrative system on the renewable energy lobby in that country. Together with a pluralistic sectoral structure, the federal system of government resulted in much more decentralised patterns of sectoral governance for the electricity industry. These patterns favoured the interests of the renewable energy lobby. Analogously to how I handled the case in the UK, here I will initially examine the benefits of these governance patterns for renewable energies in reference to technology policy: The existence of a greater variety of political arenas gave the interests of renewable energy technologies better starting points for achieving their respective research and development policies. These policies, which originated at the state level, paved the way for the technological breakthrough of wind power and proved to be decisive for further policy developments aimed at securing renewable energy technologies a secure place in the German energy market. Accordingly, I will elaborate how the technological breakthrough of wind power brought about substantive political efforts in German Parliament to issue a regulatory policy based on fixed price regulation. It was thought that this would later induce the extensive capacity building in renewable energy installations. In this context, I will finally analyse the reasons for the successful implementation of this renewable energy policy.. 


\subsubsection{The Sectoral Governance of the Electricity Supply Industry in Germany and its Impact on Technology Policy for Renewable Energy Generation}

Germany has a federal system of government, with power divided between the federation or the Bund, and 16 states or Länder. Besides the federal and the state level, the local level also plays an important role in governing, because there is a right to autonomous local government. According to the German Basic Law (the German Constitution), energy policy is part of concurrent legislation; here all levels of government have the powers to legislate, but federal law takes precedence should a conflict arise (Keating 1999). One characteristic of German federalism consists in the division of regulatory tasks between different political levels in utility regulation. In energy and electricity policy, the federal level very often legislates the broad principles, and the states fill in the details and carry out the administration. Since the states have the administrative competencies for implementing the federal laws, they are guaranteed a great deal of freedom to pursue their own objectives in energy and electricity policy.

One of the areas in which the states have regulatory competencies is in the licensing procedures for tariffs. Although the licensing procedures for tariffs are determined in a federal ruling (Bundestarifordnung Elektrizität, BTOElt), the states have a lot of discretion at their disposal in designing these licences. With licensing policy, they can pursue their own objectives, for example, promoting goals to generate energy from renewable sources. They also exert a lot of power through the administrative competencies they have for determining licensing procedures for the construction of plants and grids (Lang 1999). Even more important with regard to the issue of this paper is their power to offer financial incentives, from the reserves of their own budgetary funds, in order to achieve their own targets in energy and electricity policy. This is specifically relevant for achieving an increasing portion of the energy generated from renewable sources. As will be shown later, the public funding of specific states in northern Germany (especially in North Rhine-Westphalia and Lower Saxony) was crucial for the breakthrough of wind energy technology. In these states, specific ministries (most of them responsible for economic affairs) supported, first, the technological development of wind energy installations, and later the establishment and realisation of wind energy projects. Additionally, specific public banks (e.g. Deutsche Ausgleichsbank, Kreditanstalt für Wiederaufbau) and their branches in the different states, which are under the supervision of the Federal Ministry for Economics and Technology and the respective ministry of the state, played a crucial role in the financial support of these projects.

Concerning the industry structure, no statutory or state-wide monopoly for energy generation and supply could be established in the German electricity industry. Hence, in the late 1980s "no strictly functionally differentiated monopolies existed like in the nationalized electricity industries in the UK" (Schneider 1999). Instead, the German sectoral structure was characterised by a pluralistic industry, with a large number of utilities in possession of demarcation agreements guaranteeing them exclusive supply areas. This led to a heterogeneous structure in the monopolistic electricity utilities operating at the local (Stadtwerke), the regional (Regionalversorger) levels and the transmission system operators' level (Verbundunternehmen). According to a 
study from 1997 (Schiffer 1997), until then the sectoral industry was characterised by some 700 municipal utilities, about 60 regional utilities, and 9 transmission system operators. ${ }^{17}$ Related to this, the planning, operation and construction of utilities and their generation installations in the German electricity sector was dispersed throughout different organisational levels (local/municipal, regional, transmission system operators). Another decisive feature of the German electricity utilities consists of the significant influence that local governments (municipalities and communities) have at their disposal for sectoral governance. They have this influence because of their ownership of shareholdings - mainly of the local and regional suppliers - and their political responsibilities, based in their constitutionally guaranteed right to local government.

Therefore, the German electricity utilities are characterised by a much more mixed structure of ownership, i.e. they are more often shared by the public and private sector than the utilities in the United Kingdom. There is public influence, with the municipalities and states influencing utilities on the local and regional level. There are more electricity generating and distributing companies, which indicates the more decentralised structure of the German electricity supply industry. In this respect, the German local and regional authorities as well as the states have more political influence on governance in the utilities sector than do the authorities in the United Kingdom: This is due to the varying historical developments of the respective utility sector. In this context, "the governance mechanisms emerged through the interaction of the network characteristics with the segmented structure of the German state as well as with the interventionist philosophy of the state actors. As a result of this pattern, sectoral governance is still marked by a strong presence of municipal and state owned companies and extensive ownership linkages among the utilities" (Eising 1999). In sum, the modes of governance shaping the interaction between the German political-administrative system and the electricity industry are characterised by much more decentralised patterns.

In the following I shall verify the argument that the more decentralised and fragmented sectoral structure in the German electricity industry, together with the federal political-administrative

17 The transmission system operators play a crucial role in the German electricity market. They were and still are managing and operating the whole national electricity grid on the interconnected level. Additionally they account for nearly $80 \%$ of the total generation capacity of electricity. Until last year, the operation of the national grid through these interconnectors was coordinated within a joint association, the former Association of German Transmission System Operators (Deutsche Verbundgesellschaft (DVG)). Due to the unbundling provisions of the liberalisation directive concerning the European Electricity Market (EC/96/92), which obliges the utilities to do separate accounting of their operations in generation, transmission and distribution, the former 'Deutsche Verbundgesellschaft' has only recently been replaced by the new German Association of Transmission System Operators (Verband Deutscher Netzbetreiber). In the late 1980s the members of the DVG were: Badenwerk AG, Bayernwerk AG, Berliner Kraft und Licht AG (BEWAG), Energie-Versorgung Schwaben (EVS), Hamburgische Electricitätswerke AG (HEW), Rheinisch-Westfälische Elektrizitätswerke Energie AG (RWE), Vereinigte Elektrizitätswerke Westfalen AG (VEW), Vereinigte Energiewerke AG (VEAG). After the starting of the liberalisation in 1998, the German electricity market has melted down to only four transmission system operators. Only recently, in early 2002, the market was reorganised as BEWAG (Berliner Kraft und Licht AG), HEW (Hamburgische Electricitätswerke AG) and VEAG (Vereinigte Energiewerke AG) were taken over by the Swedish Vattenfall Group, which led to the establishment of a 'third power' in the German electricity market named Vattenfall Europe (besides RWE AG (RheinischWestfälische Elektrizitätswerke Energie AG) and E.ON Energie AG (formerly established out of the merger of Bayernwerk AG and PreussenElektra)). The EnBW AG (Energiewerke Baden-Württemberg AG) forms the fourth power in the market, which is influenced strongly by the Electricite de France (EdF). 
system, has offered representatives of renewable energy technologies a more favourable opportunity structure for achieving their political interests. In this regard, the analysis of the technology policies on the federal and state levels in Germany will help to explain the breakthrough of wind power, which paved the way for the development of stricter regulations favouring renewable energy technologies on the federal level. Precisely because large-scale technology policy on the federal level proved not to be as successful as the respective policy programmes on the state levels, policy-making and implementation at that level first positively influenced the perceptions of the policy-makers there, but later it also influenced the perceptions at the federal level, resulting in the widely held view that it is feasible to extend renewable energy generation and that such energy sources are worth extending (Hemmelskamp 1999). In this connection, public aid programmes on the state levels encouraged the development and construction of small-scale renewable energy technologies (especially wind power). The successful implementation of these programmes proved to be decisive for the later breakthrough of the Electricity Feed Act in 1991, which provided the basic incentive for the capacity building of renewable energy technologies during the 1990s. In the following I will elaborate on the favourable impacts of decentralised modes of sectoral governance for the technology policy related to renewable energy generation.

At the end of the 1980s, a growing number of single operators of wind power installations that managed to connect up with the distribution grid of mostly local and regional utilities (Paul 2001) added political weight to two associations that fought to improve the unfavourable conditions for wind power operators at that time. These were the Inland Wind Power Association (Interessenverband Windkraft Binnenland e.V.) and the German Society for Wind Energy (Deutsche Gesellschaft für Windenergie e.V.). The lobbying activities of these associations were mainly focused on support policies favouring wind power in specific states (mainly North RhineWestphalia, Lower Saxony and Schleswig-Holstein). Given that one precondition for the successful renewable energy policy in Germany is to be found in the decentralised patterns of the political-administrative system, these lobbying organisations were able to increasingly convince the political actors in the respective ministries of the states to issue political measures that exploited the technological potential of wind power.

In this context, North Rhine-Westphalia and Lower Saxony were the first German states to be convinced by these wind power associations to issue important support programmes for the development of renewable energy technologies. One of the most important and most successful programmes initiated under the North Rhine-Westphalian social democratic government in 1987 was the REN-programme (Programme for the Efficient Use of Energy and the Utilisation of Renewable Sources). In the following years, this programme served as an example for renewable energy initiatives in other German states (Staiß 2000). The general objective of this programme is to attain more efficient and more sustainable energy generation and consumption. It also focuses on the creation of new opportunities for employment, especially in small- and mediumsized enterprises. The programme is characterised by the broad scope with which it supports these targets. It encompasses measures for technological development, for demonstration projects, for energy consulting and for the further energy-related education of the staff. Until 1998 
about 24,000 projects could be carried out within that programme. It supported the construction of more than 700 wind power installations, with an installed capacity of more than $300 \mathrm{MW}$, and of about 3,300 photovoltaic installations, with a capacity of more than $11 \mathrm{MW}$. This programme has been assessed as having been very successful, especially because it secured the extension of the wind power capacity domestically when there were decreasing federal subsidies for this technology (Staiß 2000). In this connection, the existing support policies of the different states secured continuity for the operation of wired renewable energy installations when the federal level did not provide for them. Hence, it enabled the establishment of a national wind energy industry, which probably would have been harder to achieve if the states' policies had not existed.

The significance of these decentralised aid programmes is illustrated by the fact that, after such programmes proved their success on the state level (especially those in North-Rhine Westphalia), the Federal government was able to be convinced, in 1988, to issue a broader initial demonstration programme to further develop wind power. With the success of both the state aid programmes and the first demonstration programme, in 1989 the former Federal Ministry for Research and Education (Bundesministerium für Forschung und Bildung) was able to be convinced to initiate a further $100 \mathrm{MW}$ programme for wind. ${ }^{18}$ Due to the higher degree of dispersion of the programmes between different states, the respective programmes were only of smaller dimensions. As a consequence, these programmes lent themselves better to the development of smallscale wind power installations. Initially only the small-scale wind power installations proved to be competitive. Later, in the course of the 1990s, wind power installations were mildly upscaled. Until recently, this led to the mass production of installations up to $2.5 \mathrm{MW}$ in size.

Generally it must be stressed that the development and technology policies for renewable energy generation varied among the different states and depended on the composition of the respective government. To take one example, whereas Baden-Württemberg mainly supported measures in research and development and gave little support to broad measures aimed at the implementation of energy efficiency and renewable technologies, the latter initiatives were the focus of public programmes in North Rhine-Westphalia. Together with Bavaria, North Rhine-Westphalia spent most of its budget on the broad application of such measures.

\subsubsection{The Policy-Development of a First Wider Renewable Energy Policy in Germany: The Electricity Feed Act}

The following section will illustrate the further development of the German renewable energy policy in the late 1980s and early 1990s. This resulted in the enactment of fixed price regulations in the Electricity Feed Act in 1991. One pivotal prerequisite for this development had already

18 In this programme, government supported the operators of wind installations either with a $50 \%$ subsidy for the investment costs or with an $8 \mathrm{Pf}$ per $\mathrm{kWh}$ additional reimbursement on the fed-in electricity over a specified period of time. In part, the states gave additional subsidies so that in the end the operators could sometimes calculate with a $75 \%$ public subsidy for their investments, which gave the wind power industry a strong thrust at that time. 
been attained during the late 1980s: the technology programmes at the state level and later at the federal level had proven the feasibility of wind power on a larger scale. Until then, the process of feeding electricity into German grids by independent generators had been regulated by an informal associational agreement reached between the BDI (Bundesverband der Deutschen Industrie e.V.), the VDEW (Verband der Elektrizitätswirtschaft) and the VIK (Verband der Industriellen Energie- und Kraftwirtschaft e.V.). This shows the significance of co-operative modes of sectoral governance that had been established between the German political-administrative system and the incumbent industry. The sectoral coordination and governance by associational agreements is a traditional characteristic of the German electricity industry and has been highlighted by various other analyses (Schneider 1999; Böllhoff 2002). According to the associational agreement, which regulated the electricity feed-in from independent power operators, the grid operators (incumbent industry of the formerly monopolistic market) were not legally obliged to grant access to their grids to other energy generators. If access was granted, this was voluntary, and the grid operators (mainly local and regional utilities) reimbursed the fed-in electricity supplier at levels below the costs avoided. This made feed-in a profitable business for incumbent utilities. Therefore, the existing feed-in arrangements for renewable energy capacity, based on an associational agreement, had already long been criticized by the independent operators of hydroelectric power stations, the most important renewable energy band at that time (Bundesverband WindEnergie, (BWE), October 2001). However, given the public subsidies for technological development and the implementation of different states' policies, the unfavourable feed-in conditions could not prevent more and more operators from constructing wind energy installations in North RhineWestphalia, Lower Saxony and Schleswig-Holstein.

The decisive point in the agenda-setting process for the Electricity Feed Act was the establishment of an effective lobbying group for wind power in the northern part of Germany (i.e. North Rhine-Westphalia, Lower Saxony and Schleswig-Holstein), which coincided with the political lobbying of the established hydro-electric power industry from the southern states of Germany (i.e. Bavaria and Baden-Württemberg), in favour of fixed feed-in tariffs for electricity generating renewable energy installations. The hydroelectric power station operators had long striven for obligatory electricity feed-in (organised in the Federal Association of Hydroelectric Power Operators - Bundesverband Deutscher Wasserkraftwerke $(B D W)$ ). In connection with this, the successful development of the wind energy technology in some northern states, due to existing technology policies, was the main factor facilitating the establishment of a wider coalition of members in the Federal Parliament who supported the development of a law on fixed feed-in tariffs for energy from renewable sources. These coinciding developments generated the decisive background against which a cross-party alliance was formed in the Federal Parliament - between representatives from the Christian-Liberal coalition, the Social Democrats and the Green Party to enact obligatory rules for the feed-in of electricity from renewable energy sources: Some members of this alliance supported the interests of hydro-electric power (namely those members belonging to the Christian-Liberal parties of CDU/CSU and FDP). Others represented the interests of the wind energy lobby (this was more likely for the Social Democrats) (BWE, October 2001). 
In this context, the policy development of the Electricity Feed Act was influenced and decisively coordinated by an organisation that operated close to Parliament: the European Association for Renewable Energies, Eurosolar e.V. ${ }^{19}$ This organisation played a crucial role in the informal development and the later implementation of this policy. It established consistent parliamentary interest representation vis-à-vis the incumbent German electricity industry, which was represented by the German Electricity Association (VDEW). It thus guaranteed the successful development and establishment of an advocacy-coalition in support of the interests of renewable energy sources. The existence of this organisation proved to be decisive for the development and implementation of a coherent and consistent renewable energy policy in Germany in the course of the 1990s. The coordinating activities of Eurosolar facilitated a consensus between the different members of Parliament, and it enabled the Electricity Feed Act to be enacted by the German Parliament on 7 December 1990. Actually, the law was issued without a single dissenting vote. ${ }^{20}$

The contents of the law provided strong incentives for bringing renewable energy technologies onto the market: It defined guaranteed premium prices for electricity generated from renewable sources. Every operator of a renewable energy installation was eligible to receive a minimum unit price per $\mathrm{kWh}$ fed into the grid from the respective grid operator. ${ }^{21}$ This premium price was not dependent on the capacity of the electricity fed into the grid but on the development of domestic electricity prices. Hence, the German Electricity Feed Act did not place a cap on the amount of renewable energy that was eligible to receive this tariff. In contrast to the United Kingdom, the regulation of renewable energy generation is therefore law-based price regulation, with legally defined feed-in prices. Besides obligating the grid operators to reimburse the renewable energy operators with the defined premium prices, they are obligated by law to connect any renewable energy generator to their grid and to reduce that generator's produced output. Consequentially, every generator of renewable energy can count on receiving this tariff from the company of the grid who feeds in its electricity. As a consequence, this price regulation provides for investment security in the medium- and long-term planning of renewable energy generators: They are able to count on reimbursement payments over a longer period of time, and they can do so long before their real investment in respective projects.

19 This organisation was founded in 1988 with the objective of altering the operational basis of the energy system from fossil to renewable fuels.

20 During the several parliamentary hearings when the policy was being developed even the Federal Economic Ministry remained rather passive (Eurosolar, July 2001). This points to the fact that the incumbent industry, whose interests were mainly represented by the German Electricity Association (Verband der deutschen Elektrizitätswirtschaft e.V., VDEW), did not anticipate that this law would be successfully implemented. As will be shown later, only the successful performance of the law caused increasing efforts of the incumbent industry to tip the law by initiating several legal procedures in different German courts and in the end even before the European Court of Justice.

21 In the original version of the Electricity Feed Act from 7th December 1990 the rate of reimbursement for electricity generated from hydroelectric power, landfill gas and biogas was to be $80 \%$ of the average proceeds per kWh derived of the bulk of electricity sold by the utilities. For electricity generated from solar and wind energy, the rate was to be $90 \%$ of the average proceeds per $\mathrm{kWh}$. Under the provisions of this old Electricity Feed Act, the guaranteed feed-in tariffs were therefore coupled to the development of the normal electricity prices in the national electricity market. 


\subsubsection{The Implementation of the Electricity Feed Act}

In this section I will explain how the strong investment incentives defined by the Electricity Feed Act led to the effective implementation of the renewable energy capacity. Initially, the fixed price-regulations were not strongly oriented in reference to efficiency criteria. Besides being influenced by the fact that such efficiency-orientation was less important in Germany at that time - a fact that relates to the late liberalisation of the German electricity sector - the successful implementation of the Electricity Feed Act was also influenced by the characteristics of the federal structure of government, which made it possible to effectively establish renewable energy projects (due to flexible governance on the state and local levels).

First of all, the following table illustrates the successful outcome of the existing policy. It describes the tremendous growth in wind energy capacity, which can be explained in reference to the provisions defined in the Electricity Feed Act of 1991. However, it should be kept in mind that the Electricity Feed Act also induced a considerable extension of renewable energy generation capacity in biomass and hydroelectric power.

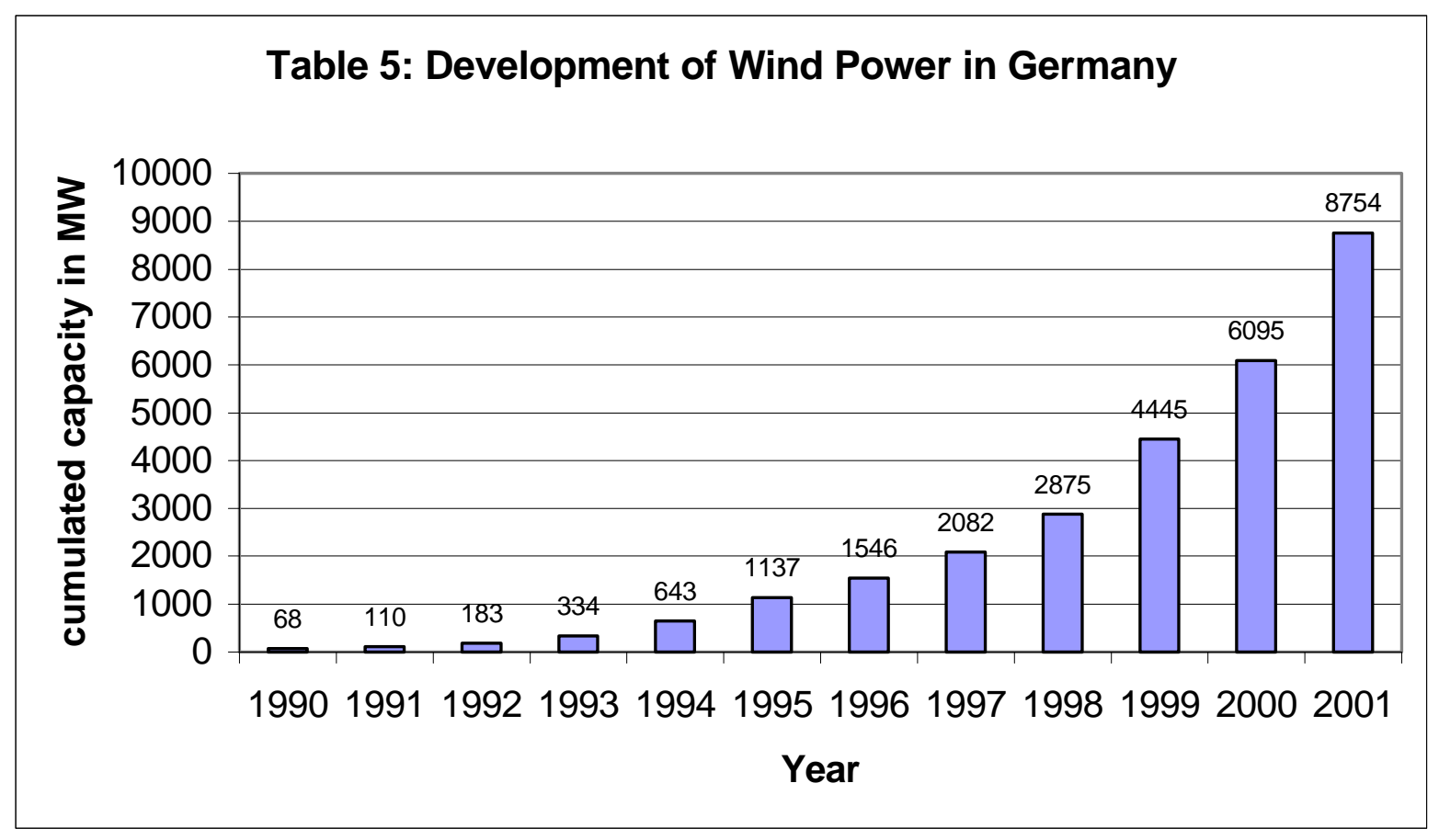

Source: Figures of German Wind Power Industry, Federal Association for Wind Power, 2001

As mentioned before, substantial price regulations are the main reason for the successful construction of renewable energy capacity in Germany. These guaranteed the operators sufficient revenues to operate their facilities. Since the tariff for these law-based regulations was higher than the one formerly stipulated in an associational agreement (equated costs avoided in electricity generation) and had to be reimbursed by the incumbent industry, the incumbent industry's resistance to these regulatory provisions increased as more renewable energy installations were constructed (Eurosolar 1995). Especially since 1995, when the number of wind power projects nearly doubled in comparison to the previous year (see table 5, this page), the incumbent indus- 
try, represented by the German Electricity Association (VDEW), has challenged the constitutionality of this law (Renz 2001). They have argued that reimbursing regulations would be an extra duty, which under German Constitutional Law is only legal under specific circumstances, and not circumstances applicable in this case. Furthermore, the regulatory provisions would conflict with fundamental rights defined in the German Constitution.

Applying this argumentation, the German Electricity Association (VDEW) recommended that its members - most of the incumbent utilities in Germany - pay the legally defined reimbursement rates only while simultaneously threatening to claim the payments back should the Electricity Feed Act be declared unconstitutional. After this recommendation, a few utilities refused to pay the legally defined reimbursement rates, and instead, only reimbursed rates for the costs avoided (as formerly stipulated in the associational agreement for electricity feed-in from hydro-electric power stations). The Cartel Offices of the states supervising these incumbent utilities immediately responded to the consciously antinomian behaviour of those incumbents. Additionally, some renewable energy operators appealed to the Federal Cartel Office to prevent some incumbents from engaging in this illegal behaviour. The threat that the Federal Cartel Office and the respective cartel offices in the states might initiate legal proceedings to check for anticompetitive practices was enough to move those incumbents to quickly pay the compulsory tariffs laid down in the Electricity Feed Act again. Therefore, the German system of checking anticompetitive behaviour with the help of the Federal Cartel Office and the various Cartel Offices on the state level contributed to the successful implementation of the Electricity Feed Act.

Related to this, the courts also played a pivotal role in defending the Electricity Feed Act against the incumbent's efforts to topple the law. From 1995 to 2000, because the constitutionality of the Electricity Feed Act was called into question by the incumbent industry, the Federal Constitutional Court looked into that act several times. In May 1996, it first resisted calling the constitutionality of the Electricity Feed Act into question when it referred a court ruling between the Badenwerk AG and the operators of a small hydroelectric plant back to the relevant district court (Landgericht Karlsruhe) (Eurosolar 1996). Another constitutional complaint against the Electricity Feed Act was initiated by a regional utility from the northern states in September 1996. The Federal Constitutional Court only recently rejected this. Further legal proceedings dealing with the constitutionality of the law were initiated in January 1997 by a regional utility from a southern state: All these proceedings call into question a court decision of the Federal Court of Justice, and they are still being negotiated. PreussenElektra and VEAG initiated further constitutional complaints in May and August 1998 (Eurosolar 1998). Until today, the Federal Constitutional Court has not denied the constitutionality of the law.

Next to the important role of the German cartel offices and courts in enforcing regulatory provisions contained in the Electricity Feed Act, the federal system of government, with concurrent legislative powers for energy regulations, proved to be beneficial to the construction of concrete renewable energy projects. On the state level, the emerging renewable energy lobby, particularly that of wind power industry, was able to successfully fight for reforms in the building laws, which facilitated the construction of renewable energy projects. Such reforms already started in 
Lower Saxony in 1992, when the construction of wind power installations was privileged in the nature conservation laws. Similar regulatory reforms followed in 1994 for North RhineWestphalia. In the context of my argumentation it is crucial to point out that the regulations privileging the construction of renewable energy installations were initially laid down in the respective regulations of the individual states. Only later did the federal government adapt its respective regulatory policy to the developments on the state level. Related to this, the reform of the federal building laws in 1996 was a decisive final breakthrough, which helped alleviate the construction of renewable energy installations on the national level. This generally privileged the construction of renewable energy installations.

In this context, the federal reforms of the Building Law in 1996 granted significant regulatory competencies to the local communities: specifically, they were allowed to define construction areas for wind power installations in their use zoning plans. By actively defining such areas, the communities were able to define the construction of such installations in locally preferred areas and they were thereby able to exclude other areas from being used as building areas for wind energy installations. This guarantee of the legislative power to define concentrated areas for constructing renewable energy installations gave local governments a sensible instrument for helping the local population accept such projects. As a consequence, this reform of the federal building laws triggered large-scale planning activity by the local communities and municipalities, specifically to define the respective construction areas for renewable energy installations. Correspondingly, the crucial role of the national planning system in concretely bringing about such projects must be pointed out. With legislative powers divided between different levels of governance, the planning system provided for the flexibility and efficiency to incorporate the renewable energy interests into federal, regional and local plans. Accordingly, the state's competencies for defining its own energy policy targets in regional and spatial planning proved to be decisive. In this context, in 1994 Lower Saxony had already defined such targets of extending renewable energy generation in its spatial planning. Similarly, North Rhine-Westphalia was one of the first German states with tasks related to furthering renewable energy generation in the different relevant planning policies.

\section{The Recent Reforms in Renewable Energy Policies of the United Kingdom and Germany}

While developments of the generation capacity from renewable sources in the United Kingdom and in Germany have been quite different, both countries have only recently reformed their renewable energy policies. In the first part of the following section, I will therefore describe the reasons for and outcomes of the respective reforms of the domestic renewable energy policies.

An analysis of the reform in the United Kingdom must take into account the impact of wider reform policies in British utility regulation, which started after the change from the Conservative Party government to the Labour Party government in 1997. In reference to one of my explanatory factors, which accounts for the less effective implementation of renewable energy generation, i.e. 
the strong orientation towards the efficiency-oriented promotion of these technologies due to the dominance of the liberalisation paradigm in sectoral policy, I will initially illustrate the reasons for wider market reforms, which started at that time in the British gas and electricity markets. In a second step, I will then describe the impacts of these market reforms on renewable energy generation. Finally, I will refer to the reform of the renewable energy policy, i.e. the development of the Renewables Obligation, which was due to the worsening conditions for providing this kind of electricity generation under the new market arrangements. The contents of this new instrument point to the relevance of the other explanatory factor, i.e. the significance of the central government for the policy development. However, the changing perceptions in British government, which increasingly focused on this generation technology, served as an impetus to the development of an increasingly intrusive approach to the issue of renewable energy generation.

In a second part, I will analyse recent reforms of the German renewable energy policy. Despite the successful implementation of the German Electricity Feed Act, the federal government had to reform its policy. This reform was due to the increasing resistance of the incumbent industry to the self-regulatory provisions contained in the former law. When these problems became increasingly apparent in the course of the 1990s, the attention of the policy-makers was directed to the need to improve the design of the law in order to guarantee a more just distribution of the reimbursement costs in the utilities sector. Similarly to the reform in the United Kingdom, the reform in Germany accompanied a change in government: In 1998 a coalition of Social Democrats and the Green Party came into power. In their election campaign, they favoured extending the existing policies for renewable energy generation. The table below provides for an overview of the reasons for the recent reforms of the renewable energy policy in both countries.

Table 6: Triggering Factors for Recent Reforms of Renewable Energy Policy in the United Kingdom and Germany

\begin{tabular}{|c|c|}
\hline United Kingdom & Germany \\
\hline Change in Government in 1997: Labour Party & $\begin{array}{l}\text { Change in Government in 1998: Government Coali- } \\
\text { tion of Social Democrats and Green Party }\end{array}$ \\
\hline $\begin{array}{l}\text { Market Reforms of the Electricity Market / New } \\
\text { Framework for Utility Regulation (Utilities Act } \\
2000) \rightarrow \text { shift in sectoral regulation, more strongly } \\
\text { accentuating social and environmental objectives }\end{array}$ & $\begin{array}{l}\text { Liberalisation of National Electricity Industry in } \\
1998 \\
\rightarrow \text { increasing pressure for more efficiency- } \\
\text { orientation in renewable energy policy }\end{array}$ \\
\hline $\begin{array}{l}\text { Greater focus on renewable energy policy within } \\
\text { the new regulatory framework due to: } \\
\text { - diffusion of climate policy targets into sectoral } \\
\text { policy (impacts of Kyoto and the national com- } \\
\text { mitments of the United Kingdom) } \\
\text { - ineffective implementation of existing policy } \\
- \text { consideration of the success of renewable en- } \\
\text { ergy technologies in other European countries } \\
\text { (Spain, Germany, Denmark) } \\
\text { - prediction of change in the structure of fossil } \\
\text { fuel resources for the next decades }\end{array}$ & $\begin{array}{l}\text { Reforms of renewable energy policy due to: } \\
\text { - unidimensional support of wind power, biomass } \\
\text { and hydro-electric power under the old regula- } \\
\text { tory provisions } \rightarrow \text { extension of political support } \\
\text { to other renewable energy technologies (e.g. } \\
\text { photovoltaic, geothermal energy) } \\
\text { - adaptation of existing regulations to competitive } \\
\text { market conditions } \\
\text { - solving the increasing problems of implementing } \\
\text { the Electricity Feed Law by imposing the incum- } \\
\text { bent industry to a self-regulatory national cost } \\
\text { burden-sharing mechanism }\end{array}$ \\
\hline
\end{tabular}




\subsection{The British Reforms as a Window of Opportunity for a Reorientation in Renewable Energy Policy?}

As described previously, the fundamental aim of utility regulation in the United Kingdom since the start of the liberalisation policies in 1989 has been to establish competitive market structures in the electricity and gas markets. However, the establishment of such structures has proven to be an exceedingly difficult task, especially in the generation market. Immediately after Labour took over power in 1997, it started deliberations for further fundamental reforms in the utility industry, specifically in the gas and electricity industries. As in the reforms in the late 1980s, this time the reform consultations also remained committed to the objective of increasing the efficiency in the electricity sector so as to benefit the end user. Nevertheless, these reforms were also accompanied by a slight shift in sectoral regulation, leading to a stronger accentuation of the social and environmental objectives of the utilities. Whereas utility regulation under the Conservative Party government relied unilaterally on the belief that free market economics could efficiently allocate resources to the benefit of all market participants (Jones 2000), their 'non-interventionist approach' of regulating utilities became the focal point of public criticism due to increasing deficiencies in the efficiency and quality of the utilities operation. The growing discontent with the poor quality of service, the high salaries for directors and the generous dividends for shareholders made utilities increasingly unpopular in the eyes of the British public (Young 2001). Because of that, the distributional implications of introducing competition, which had not been a political issue in the Labour Party discussions before the 1997 election, became a central focus for the party (Currie 1997). Consumer organisations especially recommended making consumer protection a higher priority in utility regulation. ${ }^{22}$

After the 1997 election brought Labour into government, the Department of Trade and Industry comprehensively reviewed utility regulation. This review resulted in a Green Paper in spring of 1998 entitled 'A Fair Deal for Consumers' (Department of Trade and Industry 1998). This Green Paper accentuated the social dimension of the governmental regulatory duties. What is even more important with regard to our issue is the Labour government's declaration of intent: The new regulatory framework for the utilities should "reflect the importance of the utility industries to the achievement of wider social and environmental objectives" (Department of Trade and Industry 1998). Acknowledging the major impact of the utility industry on the environment, the regulatory framework was to be "set in the right way to ensure a positive contribution by the utilities to the environmental objectives of the Government's strategy for sustainable development" (Department of Trade and Industry 1998). Against the background of the conclusion of the Kyoto-Protocol, the new Labour government strove to give government policy a greener image by declaring ambitious targets in climate policy. This provided the impetus to use the utility

22 This requirement was justified under the impression that the regulatory system generally worked against those on low incomes. Since the RPI (i.e. the formula for price regulation on consumer tariffs, A.S.) is based on average prices for each item included, people with lower income were supposed to have paid relatively more. Furthermore regional differences, which could be substantial, were not reflected adequatelly in the benefits (Young 2001). As a consequence, the new Labour Government called for a new framework of utility regulation that "needs strengthening to improve accountability and achieve the right balance of interests between consumers and shareholders." (Department of Trade and Industry 1998). 
reforms as an opportunity to reform the renewable energy policy as well. However, the main reason for the fundamental reforms in utility regulation was to better protect consumer interests. As a consequence, the further development of the renewable energy policy in the United Kingdom remained strictly committed to a market-based approach. Representatives of very different interest groups from industry, society and public administration participated in the consultation processes for the reform of utility regulation, which finally led to a new framework for the gas and electricity markets, i.e. the Utilities Act 2000 (Graham 2000). ${ }^{23}$

Correspondingly, the most important part of this reform was the reform of the trading arrangements for electricity, i.e. the abolishment of the Electricity Pool and the creation of the New Electricity Trading Arrangements (NETA). This reform was supposed to bring the benefits of liberalisation back to the consumers by furthering competition, mainly in the generation market. Related to this, the establishment of a more efficient and transparent trading market for electricity aimed to bring prices down further. The primary importance of market creation issues is illustrated by the fact that the policies referring to that issue, i.e. the New Electricity Arrangements (NETA), could already be established in March 2001, while reforms for a renewable energy approach (i.e. the Renewables Obligation (RO)) were only able to be put into practice in April 2002. Again, reforms aimed at creating a more efficient electricity market preceded re-regulatory policies to support renewable energy technologies. Because the Renewables Obligation was not established until spring 2002, there are indications that operators of renewable energy installations and of other independent energy generators (such as combined heat and power) have increasingly been suffering from the operation of NETA since they were established in March 2001. To illustrate the impact of NETA on independent energy generators such as renewable energy operators, I will now describe the operation of NETA in more detail. I will then conclude with a description of the contents of the Renewables Obligation (RO), which aims to solve the described policy problems, since it provides for a new policy to support energy generation from renewable sources.

23 The most important provisions for a basic reform in utility regulation in the gas and electricity market were driven primarily by the goal of promoting effective competition and benefiting consumers. For that reason, the following measures were realised: legislation to underpin new electricity arrangements that were to be established to further bring down electricity prices, the merger of the former gas and electricity regulators (OFFER and OFGAS) with an Authority (Office for Gas and Electricity Markets, OFGEM); a duty on this Authority, in the exercise of its statutory functions, to have regard to guidance issued by the Secretary of State, on the social and environmental objectives relevant to the gas and electricity sector; and finally, and most important for the issue of this article, new powers for the Secretary of State to make regulations to promote energy efficiency, the generation of electricity from renewable sources, and to provide for a cross-subsidy to benefit disadvantaged consumers. 


\subsubsection{The Recent Reforms in the Gas and Electricity Markets: From the Electricity Pool to New Electricity Trading Arrangements (NETA)}

Despite the undeniable achievements of the Electricity Pool, ${ }^{24}$ it is important to refer to the problems of this virtually real-time pricing mechanism, which inevitably tended to produce volatility in prices. To solve this problem, the Pool has been overlaid with both short- and long-term contracts (known as contracts for differences, CfDs) that make capacity and energy prices more predictable for both customers and generators. As a consequence, incumbent generators have not had "to place a realistic bid into the Pool, because the price paid by the purchaser to the generator ultimately has been determined by a contract" (Thomas 1996). Since they owned the entire plant (old coal- and oil-fired stations), which is only required intermittently (on mid-merit load) and which is decisive in determining the System Marginal Price of the Pool, the incumbents of the generation market (shortly after privatisation only the National Power and PowerGen) were able to predict with some precision which Pool bids would be at the margin. They therefore had a significant influence on setting the Pool price (Thomas 1996). ${ }^{25}$ As a result, incumbent generators had "scope to force Pool prices up or down in the knowledge that most of their income was covered by contracts for differences which were independent from Pool prices. They have been able to make excessive profits with the marginal plants which set the Pool price and which were not covered by contracts by bidding them well above economic costs" (Thomas 1996). This proved to be one of the main reasons for the inefficiencies of the Electricity Pool, which eventually resulted in abolishing it and in introducing New Electricity Trading Arrangements (NETA) in $2001 .^{26}$

24 In one of his consultation papers the Director General of Energy Supply named the achievements of the Pool trading arrangements: "They have enabled generating plant to compete in terms of offers to run, and have enabled plant to be ranked and scheduled in order to meet expected demand. The quality and securities of supply have also been maintained. (...) Access to the Pool has assisted new generators in entering the market and the arrangements have allowed competition in supply to be introduced" (OFFER 1997). For a short description of the operation of the former trading arrangements under the Electricity Pool see footnote 12 on page 11 .

25 The Pool prices were determined by the System Marginal Price (SMP). The decisive generators determining the SMP were the intermittently operating power stations. Basic load power stations usually bid zero into the system because they were dependent on inclusion in the Unconstrained Schedule. Actually, $85 \%$ of such intermittently operating power stations were run by the two incumbents, PowerGen and National Power, which were thus able to exert a significant influence on the SMP. As a consequence of the incumbents' power to influence the Pool Price, the former DGES introduced price controls on the pool price, which were conducted nearly every year. Accordingly, most complaints critised that prices were too high and variable (referring at different times to System Marginal Price) (...); further points for criticism were "that customers cannot participate directly in the Pool (only one-sided market for generators); and that the Pool does not respond to their concerns" (OFFER 1998). Furthermore, "a lack of competition in generation to perceived or actual abuse of market power, the arrangements for bidding and price setting, the compulsory membership of the Pool and the slow pace of exploration and implementation of reforms" (OFFER 1998) have been core criticisms. The complexity and opacity of the price setting process would also have inhibited the development of derivates markets and would have reduced liquidity in the contracts market.

26 The new electricity trading arrangements were based on bilateral trading between generators, suppliers, traders and customers. They were to consist of: (1) forward and future markets, operating up to several years in advance and evolving in response to the demand of participants; (2) a short-term bilateral market, operating from at least 24 hours before a trading period commences, to give market participants the opportunity to 'fine tune' their contract positions; (4) a balancing mechanism in which the National Grid Company (NGC), as a system operator, accepts offers and bids for increasing or decreasing the generation or the demand to enable 
Generally, the development of the new electricity trading arrangements was accompanied by a closed consultation process between the technical experts of the new regulatory authority for the gas and electricity markets, OFGEM (in 1998, after the merger of the sectoral regulators for the gas market (OFGAS) and the electricity market (OFFER)), the DTI and several stakeholders of the electricity supply industry. The interests of small generators, such as renewable energy operators and CHP operators were integrated into the consultations as much as possible; but this was still limited given their restrained organisational and technical capacity in comparison to the incumbent generation industry. Moreover, this proved to be difficult to achieve since developing the new electricity trading arrangements was a highly technical task.

\subsubsection{The Impacts of NETA on Operators of Renewable Energy Technologies}

The NETA started its operation's on 27 March 2001. Since then, the first reviews of the performance of the new trading arrangements have been conducted by OFGEM. Concerning the main target of the reforms, i.e. the desire to force competition in the generation market and bring prices in the wholesale market further down, the reforms proved to be successful. ${ }^{27}$ As a consequence, smaller generators, such as renewable energy generators and CHP operators, had substantially decreasing revenues. On average, the prices for their exports went down by 17 per cent. Export prices for wind power decreased even more than usual, i.e. by 27 per cent (OFGEM 2001a). As a result, the introduction of NETA has put smaller energy generators, who do not fall under the regulations of the NFFO orders ${ }^{28}$ under further pressure.

Under NETA the major problem of small renewable energy generators is their weak negotiation position. The main reason for this is the lack of ability to predict the generation output for some technologies (especially of wind power). Under NETA, this lack of predictability jeopardizes the operation of such technologies, because it makes it more likely that they will suffer from imbalance charges when signing the BSC, which sanctions deviations from the predicted supply and demand in order to keep the national grid in balance. In accordance with this weak negotiation position, the vast majority of smaller generators (98 per cent) opted for the local supply option (OFGEM 2001a). In line with this contracting strategy, small operators normally have to negotiate their generated output for one year with the local supplier where they feed in their generated output. Due to the fact that this short-term contracting strategy is rather unfavourable for smaller and independent generators, it is necessary to make it possible for them to more actively participate in NETA. This participation should make it possible for them to engage in longer-term bargaining under NETA. Therefore small generators should be required to consolidate their gener-

it to balance the system; and (4) a settlement process, which would be required for charging participants who do not have a balance between their contracted position and their metered volumes of electricity.

The "prices available under NETA are substantially lower than had been available under the Pool. (...) In summary, we believe NETA has resulted in wholesale prices 20-25 percent below those which the Pool would have produced" (Letter from Callum McCarthy to Energy Minister, Brian Wilson MP, 31st August 2001).

28 Whereas at the end of 1997 , about 83 per cent of the renewables capacity (excluding large scale hydro) was covered by Renewable Orders, due to the expiry of NFFO 1 and NFFO 2, this share was reduced to around 30 per cent by July 1999 (OFGEM 1999). 
ated output. ${ }^{29}$ The bundling of generation output from different renewable energy generators should make it possible to better predict the potential output of specific generation technologies (e.g. wind power) (OFGEM, November 2001). It should make it possible for small independent generators to disseminate the risk of participating in the Balance and Settlement Codes. OFGEM and DTI try to improve their situation by encouraging them to make use of these cooperating strategies. With this in mind, OFGEM formed an informal Consolidators Working Group to support measures that facilitate the development of such consolidation services (OFGEM 2002). However, whereas opportunities for the successful implementation of such consolidation strategies exist at the margins, there seems to be a failure to appreciate the physical limits of such strategies precisely because NETA are built for, and dominated by, large-scale plants, capable of delivering predictable power flows (Helm 2002). For that reason, OFGEM has only recently changed NETA arrangements to provide smaller and independent generators a more favourable basis for consolidation: They are now able to split their generation output into two products. One is the predictable part of their output, which they can normally sell to their customer, e.g. the traditional electricity supplier. The less predictable output is to be sold to electricity trading companies, which are supposed to consolidate the output of smaller generators and thus minimize their risk (Bauknecht 2002).

A second, more general concern related with the operation of NETA refers to the supposition that further price decreases in the wholesale markets would unfavourably affect the investment climate for new generation facilities. The new trading arrangements are criticized for failing to provide a framework for the sorts of long-term contracts necessary to finance the sunk costs of generation (Helm 2002). With the full liberalisation of supply in 1998, it was no longer certain that suppliers would be able to recover long-term sunk costs by passing them on to customers that are no longer captured in the liberalised market. Theoretically, the risks of long-term investments should be absorbed by the emerging financial markets, 'but in practice, the forward markets are extremely weak, and are unlikely to provide a vehicle for hedging risks over ten, twenty or even thirty years for the foreseeable future' (Helm 2002).

\subsubsection{The Renewables Obligation}

As mentioned earlier, the change from the Conservative Party to the Labour Party government in 1997 heralded a substantial change in the national utility policy, which lent sectoral regulation a more social countenance. The substitution of the one-party government was accompanied by significant reforms in the electricity and gas sector, initially rather of the market-oriented kind but recently also aimed at better achieving the environmental objectives of this sectoral policy. In

29 Consolidation is a means by which the unpredictable outputs of a number of generators (especially those using renewable energy sources, such as wind power) can be aggregated, in some cases in conjunction with demand, such that the unpredictability of the total is less than the sum of the unpredictabilities for each individual generator / demand. A consolidator has been described as a BSC Party which offers services to smaller generators to allow them access to the NETA mechanisms and to the benefits of consolidation (OFGEM 2001a). Consolidation services are perceived as a crucial regulatory strategy by OFGEM and DTI, needed to strengthen the market position of smaller generators. 
this regard, current reforms concerning renewable energy generation are also due to changes in the perceptions of political actors about such technologies.

First of all, the upcoming challenge to provide concrete measures to counter global warming lent new attention to renewable energy technologies. In this regard, the international negotiations on climate change that resulted in the Kyoto-Protocol of 1997 were also instrumental in generating more support for a more active policy for renewables. But the successful construction of respective renewable energy capacities in other European countries during the 1990s (besides Germany specifically in Denmark and Spain) might have also swayed the UK government to provide a more substantial policy in that area. Hence, increasing problems in implementing the NFFOpolicy, ${ }^{30}$ together with an increasingly positive view of renewable energies, as one element of a significant and feasible strategy for combating global warming, resulted in reform efforts targeted at improving the situation for renewable energy technologies. As elaborated before, these efforts must be analysed against the background of the general reforms of the regulatory framework for utility regulation. Keeping this in mind, part IV of the Utilities Act 2000, which is the result of the general regulatory reform of the utilities and provides for the new regulatory framework for utility regulation, describes the amendments of the Electricity Act 1989 in order to adapt the old regulatory provisions to the new regulatory framework. Section 32 of the new Electricity Act contains a regulatory provision for a new policy instrument aimed at promoting renewable energy sources, i.e. the Renewables Obligation (RO).

The Renewables Obligation for England and Wales (RO) ${ }^{31}$ and the equivalent Renewables Obligation for Scotland (ROS) will place a "legal obligation on all licensed electricity suppliers to produce evidence that either they have supplied a specified proportion of their electricity supplies from renewable energy sources to customers, or that another electricity supplier has done so. Suppliers are required to produce evidence of their compliance with this obligation to the Authority by a specified day each year. Evidence can be via certificates which the Authority (Office for the Gas and Electricity Markets) issues and/or paying buyout”(OFGEM 2001).

The latter refers to the increasing role of the sectoral regulator, i.e. the Office for Gas and Electricity Markets (OFGEM), in achieving environmental targets in energy policy. Correspondingly, the implementation of the RO will extend the regulatory functions of OFGEM. It will be the regulatory body responsible for implementing and monitoring the RO (OFGEM, November 2001). ${ }^{32}$ Hence, the introduction of the RO is a further indication of the shift in the contents of the regulatory duties from a focus on pure economic issues of market creation to broader social issues (here also environmental objectives). It illustrates that privatisation and liberalisation do

30 In this context, the current reform of the national planning system in the United Kingdom is an important accompanying policy reform to support the extension of renewable energy technologies in the near future (Department for Transport, Local Government and the Regions 2002).

31 Large hydroelectric stations (over $20 \mathrm{MW}$ ) and energy recovery from the incineration of waste (unless it is biomass such as forestry material) are excluded from the RO.

32 As regards the implementation of the Renewables Obligation, OFGEM is supposed to fulfil the following functions: accrediting generators, issuing Renewables Obligation Certificates, assessing compliance, adjusting the buy-out price by the RPI each year, receiving and recycling buyout and reporting annually on compliance with the Renewables Obligation (OFGEM 2001). 
not necessarily whither away the regulatory obligations of the governmental and sectoral regulators once competition in the sector has been successfully established (Bauer 2002). Because the RO will place an obligation on all licensed electricity suppliers in England and Wales to take a growing percentage of their total sales from eligible renewable sources, the implementation of the RO implies that there has been a significant shift in the UK policy on renewable energies. The obligation on each supplier is expected "to rise from $3 \%$ of sales in the first obligation period, ending on 31 March 2003, to 10.4 per cent of sales in the year ending 31 March 2011. It is proposed that the obligation will then remain at least constant at 10.4 per cent of sales until 31 March 2027, but may well be increased to meet more ambitious targets for renewables beyond 2010" (Department of Trade and Industry 2001). The RO was just enacted in April 2002. The first significant results from this are not expected before the end of 2003.

In this context, the persisting characteristics of the renewable energy policy in the United Kingdom must be pointed out. As with NFFO, the government will remain strongly committed to a market-based and efficiency-oriented approach to bringing renewables onto the market. Under the RO, the suppliers will comply with the objectives of the obligation, buying the prescribed shares from the cheapest and most efficient sellers of renewable energy on the British wholesale market. Furthermore, generators using renewable sources are now forced to trade their output as earlier described. This puts them under strong pressure to reduce costs. In accordance with the policy development of the NFFO policy, the development of the RO was dominated by the central government, involving mainly DTI and OFGEM.

\subsection{The Reforms of the German Renewable Energy Policy: The Renewable Sources Act 2000}

In the subsequent section I will shortly summarise the increasing implementation problems of the former Electricity Feed Act. Despite of being very successful in expanding renewable energy generation from wind, biomass and hydro-electric power, it was exactly this success that required adaptions of the regulatory provisions. The reforms were also due to the liberalisation of the German energy market in April 1998, which threatened the continuity of the existing regulations for renewable energy generation. In the following section I will describe the reasons, which made the reform necessary, before I will then elaborate the contents of the new regulatory policy.

\subsubsection{The Increasing Need to Reform the Electricity Feed Act}

The implementation of the German Electricity Feed Act proved to be remarkably successful, especially in creating a new capacity for wind energy (see table 5 on page 24). However, the unexpected success of the Electricity Feed Act forced the German legislator to make further reforms. The tremendous success in expanding the capacity of renewable energy generation, especially from wind power, was one reason for the first reform of the law, in April 1998. This was 
only meant to fill the gaps until a more fundamental reform was agreed upon: This fundamental reform led to the Renewable Sources Act, which came into force in April 2000.

With the growth of wind energy installations, specifically in the maritime regions of Germany (especially in Lower Saxony and Schleswig-Holstein), some local and regional utilities, especially from the northern states of Germany, were charged with higher reimbursement costs than other utilities (these most often occurred in the southern parts of Germany). This is because of the higher concentration of renewable energy generators in the north. In order to prevent such discrimination against some grid operators, a hardship clause was introduced to the reform in April 1998: If more than five per cent of the electricity amount sold by a utility provider within one year stemmed from renewable sources, the additional reimbursement costs, above this five percent ceiling, had to be borne by the next grid operator level (i.e. there was a transfer of the cost burden from the local operators (Stadtwerke) to the regional operators (Regionalversorger), and from the regional operators to the transmission system operators (Verbundunternehmen)). Nevertheless, the increase in the wind power energy in some regions was too sharp: Only one year later, in 1999, one of the transmission system operators announced that its five per cent ceiling would already be achieved within a few months. As described previously, the tremendous success of the Electricity Feed Act had already resulted in increased resistance from the incumbent electricity utilities since the mid-1990s. Especially those that were significantly affected by the obligation to pay threatened to boycott the implementation of the Electricity Feed Act if a more just distribution of costs would not be found.

Besides these problems, concerned with the discrimination of reimbursement, other developments related to the effects of the market liberalisation indicated a need for more fundamental reforms in the renewable energy policy. With the reform of the Federal Energy Law in April $1998,{ }^{33}$ the electricity market in Germany was liberalised. By prohibiting the existence of demarcation contracts that formerly guaranteed single utilities protected sales areas, the monopolistic sectoral structure of the German electricity market was abolished. As a result of falling world market prices for fossil fuels, electricity prices had already declined before liberalisation started in Germany. Already faced with the prospect of further price decreases, expected in the increasingly liberalised and competitive market, the operators of renewable energy installations also had to fight with decreasing tariffs since the Electricity Feed Act coupled the feed-in tariffs for renewable energy with the development of electricity prices. For that reason, German renewable energy generators had to fight with decreasing revenues for their feed-in as well. In order to guarantee a secure investment basis for such generators, the German renewable energy lobby thought it was necessary to decouple feed-in tariffs from the development of electricity market prices.

33 This law transposed the provisions of the European Liberalisation Directive for the Electricity and Gas Markets (Community Directive 96/92/EC for opening the electricity markets and the Community Directive 98/30/EC for opening the gas markets). 
These problems with the Electricity Feed Act induced a fundamental reform in this policy, which in 2000 resulted in the Renewable Sources Act. The contents of this new law are described in the following section.

\subsubsection{The Renewable Sources Act: The Further Development of the Existing Renewable Energy Policy in Germany}

For the reasons mentioned in the previous section, the new German government, elected in 1998 - a coalition of Social Democrats and the Green Party - decided to reform the renewable energy policy and to realise their election promise concerning the expansion of renewable energy generation. This reform was also deemed necessary since the previous provisions of the Electricity Feed Act had not sufficiently underpinned specific renewable energy technologies. Apart from the successfully constructed installations in wind power, biomass and the small installations for hydro-electric power, other technologies which were were supposed to have a much greater marketing potential (like photovoltaic and geothermal technologies) should be given more support under the provisions of the new law. Therefore the respective price regulations were better adapted to the specific needs of these technologies to realise this marketing potential. The Renewable Sources Act especially strengthened the support for those renewable energy technologies that - under the former provisions - were not privileged to the same extent as wind power and hydroelectric power. ${ }^{34}$

Furthermore, the problems with the self-regulatory implementation of the former Electricity Feed Act indicated the need for reforms. As described earlier, the uneven distribution of costburdens between utilities, due to the differing concentration of wind power installations in the supply areas, intensified the resistance of the adversely affected utilities to the reimbursement obligations defined in this law. Another important modification that characterises recent reforms is therefore the establishment of a nation-wide equalisation scheme that aims to provide fairer distribution of reimbursement costs among the utilities. Related to this, it is regarded as essential for the German renewable energy policy that the equalisation scheme operates successfully and smoothly. It represents an interesting case of hierarchically imposed self-regulation on the electricity industry: it obliges the utilities to provide a calculation scheme on their own in order to balance the rising reimbursement costs among the different levels of grid operators. This very technical task is to be achieved by the newly founded Association of the German System Operators. $^{35}$

In this connection it must be stressed that the definition of minimum prices in the Renewable Sources Act does not automatically imply the long-term subsidisation of renewable energy tech-

34 The Renewable Sources Act defined the following premium prices for the different technology bands: wind power 17.8 Pf/kWh, photovoltaics $99 \mathrm{Pf} / \mathrm{kWh}$, biomass 17-20 Pf/kWh (depending on the capacity of generated output, hydro power, landfill and sewage gas 13-15 Pf/kWh (depending on the generation capacity), geothermal installations 14-15.5 Pf/kWh.

35 As an association with a membership representing 87\% of the German grid (comprising all German interconnectors, 38 regional operators and 226 local operators), it is the only corporative actor that possesses detailed information concerning the energy balances of the different electricity utilities in Germany. 
nologies. In order to cut costs for energy generation from renewable sources and hence to increase the generation efficiency of the respective technology band, the Renewable Sources Act introduced decreasing reimbursement rates for the different technology bands over the following years. In this regard, the Renewable Sources Act takes into account the increasing need for a competitively priced renewable energy generation. The growing consideration of this challenge is due to the newly liberalised German electricity market. Additionally, every two years the Federal Ministry of Economics and Technology is obliged to deliver a report on the progress of the law, taking view of the market introduction and the cost development of power generation installations that use renewable sources. It is also to propose adjustments to the respective reimbursement rates for the technology bands as well as future reduction rates. This should allow adapting the price regulations for the different technology bands to the respective technological progress and market developments.

Besides the described reform of the Electricity Feed Act, which resulted in the Renewable Sources Act, the federal renewable energy policy has been accompanied by another important public programme aimed at introducing renewable technologies to the market, i.e. the Programme for 100,000 PV-Installations on Roofs. In conclusion, the Renewable Sources Act implied a systematic continuation of the former Electricity Feed Act. Whereas on the one hand it will continue to increase political support for many renewable energy technologies, on the other it increasingly differentiates between the various characteristics of the different technology bands and their specific needs of being subsidised. Accordingly, it reflects the new environment wherein renewable energy projects are now implemented, i.e. the increasingly competitive German electricity market.

\section{Conclusions: The Main Results of Comparing Renewable Energy Policy in the United Kingdom and in Germany}

The comparison of the renewable energy policies in the United Kingdom and in Germany has been able to demonstrate the relevance of different political-administrative systems (unitary state structure versus federal state structure) as well as the relevance of the sectoral governance of the electricity industry (centralised versus pluralist structures of governance) on the respective policy development and implementation. Additionally, different starting points of sectoral liberalisation had significant impacts on these issues. It has illustrated the impacts of different institutional settings in the political-administrative system and of the varying policy paradigms that dominated sectoral policy (here liberalisation policies) on policy-making aimed at renewable energy generation.

Whereas the decentralised structure of governance between public and sectoral actors was favourable to the policy development, which made possible an early breakthrough in renewable energy technologies in Germany, the starting point for setting the agenda for this sort of policy was less beneficial in the United Kingdom. There, features of the unitary political-administrative system and monolithic modes of sectoral governance, in combination with an early focus on an 
efficiency-oriented sectoral liberalisation in the late 1980s, resulted in significant hindrances to the adoption of substantive regulations for promoting renewable energy sources. In contrast to that, the rather late sectoral liberalisation in Germany seems to have had a favourable impact on the adoption of regulations targeted at bringing renewable energy technologies onto the market.

The conditions from which a substantial support policy started were less favourable in the United Kingdom than in Germany. First of all, the structure of the industry was characterised by its historical heritage: Having been a nationalised industry until 1989, it was long characterised by centralised patterns of organisation and governance. Relying on the example of technology policy, I was able to indicate how the centralised modes of governance resulted in less successful technology policies for renewable energy generation. Generally, the political-administrative system of the United Kingdom proved to be less permeable to the innovative interests of renewable energy technologies. In contrast to Germany, where the decisive momentum for substantial price regulations originated in the political activities of specific states, the initial policy that aimed at supporting renewable energy generation in the United Kingdom was initiated by the central government (by the former DoE) in a top-down approach. It implied a strong role for government in bringing renewables onto the market (definition of eligible capacity, definition of technologies) and resulted in rather moderate objectives to establish a renewable energy generation capacity. Targeted at achieving the most efficient use of renewable energy sources in the newly liberalised market, the policy was based on the principle of quota regulation. But even the moderate objectives proved to be difficult to achieve. On the one hand, the analysis of the implementation of the renewable energy policy pointed to negative impacts, originating from the unitary characteristics of the political-administrative system. In this regard, the lack of both efficiency and flexibility in the centralised national planning system clearly kept the policy from being implemented more successfully. Additionally, further deficiencies inherent in the policy instrument also interfered with the implementation. In sum, the early focus of sectoral policy on liberalisation and privatisation hindered a more thorough policy for advancing renewable energy technologies, since political actors were clearly focussing on the impacts of such policies on the existing generation technologies, i.e. mainly coal and nuclear power.

With the change in the government that brought Labour into power in 1997, further reforms were undertaken in the British electricity market. These reforms introduced new trading arrangements for the generation market, but they still indicate the dominance of the sectoral objective of creating an efficient and competitive market for electricity generation. However, aggravating repercussions of the market reform on independent renewable energy generators, together with a change in the perception of the British government about renewable energy technologies, has directed political attention to the necessity of developing a more substantive renewable energy policy. This resulted in the recent adoption of the Renewables Obligation in April 2002. This policy change was also due to the fact that the new ruling Labour Party favours giving utility regulation a more social countenance. Together with the increasing relevance of climate change issues, indicated by the adoption of the Kyoto-Protocol, the UK government has felt forced to 
implement a more successful strategy for bringing about compliance with their climate change targets.

Generally, it could be added that over the last decade ongoing market reforms in the electricity generation market have imposed significant constraints on public administration, making it difficult to provide for a stable and continuous renewable energy policy. The clearly dominating focus on consumer interests in first place, which has been central in the sectoral policy of both the Conservative and Labour government, has resulted in concentrating on trade reforms, which have primarily aimed at cutting wholesale prices. This points to the dominating policy paradigm in the sectoral policy of the United Kingdom during the last decade, i.e. the belief that all aspects of the energy market should be liberalized as competitively and efficiently as possible so as to benefit consumer interests. In some respects this was detrimental to the establishment of renewable energy generation in that country. Because, from 1998 to 2001, there was no effective policy instrument for renewable energy generation during the trade reforms, the British renewable energy policy has been characterised by fragmented and interrupted patterns. While the efficiency-oriented support policy of the early 1990s prevented both a significant renewable energy industry from being established and interests that could have lent more and earlier attention to this policy issue from being represented, recent reforms in the renewable energy policy have been developed by the central government itself. The new policy contains elements of the former efficiency-oriented approach, while also setting out to improve the situation for renewables in the United Kingdom. Hence, it reflects the influence of both the still dominant objective of bringing renewables onto the market as efficiently as possible and the increasing need to comply with ambitious renewable energy targets, which were only recently adopted by the new national climate change programme.

Interestingly enough, current reforms in the renewable energy policy in the United Kingdom have been accompanied by a general transformation of the regulatory competencies of the central administration. More and more powers are being transferred to the regional and local levels of government. Whereas a lack of power to define and establish sustainability targets on the regional and local level was perceived as a crucial impediment to successfully implementing renewable energy projects, current reforms of the national planning system aim to solve this problem. This is to be achieved by delegating more regulatory and legislative powers to the local and regional level - in short so that they can define and set up sustainable development targets: This is meant to increase the capacity of these levels to attain more effective policies for sustainable energy supply. As a consequence, the reforms should also help to break up the resistance to renewable energy projects that originate at these levels. These general developments seem to support the initially stated argument: namely, that decentralised patterns of energy generation benefit from decentralised structures of governance such as those inherent in the federal system of government in Germany. In this connection, the present analysis supports the results of other comparative studies that "the advantage of federalism in comparison to unitary states is its margin for innovation which it lends to the regional and local level for political action" (Braun 2000). 
Accordingly, the federal system of government in Germany was better suited to the requirements of decentralised energy generation: The co-existence of policy-making competencies and concurrent legislation in the German energy policy at the federal and state levels provided for additional access points, which proved to be susceptive and permeable to the interests of specific renewable energy technologies. First of all, the state level was a further political arena committing diverse policies to the technological development of renewable energy generation. Specific states led the way in the breakthrough of wind power, which was later the main contribution to the tremendous increase in renewable energy generation. After this technology was successfully developed, an effective advocacy coalition, favouring the diverse interests of renewable energy technologies from the various states, could be established at the federal level. This coalition successfully fought for fixed premium price regulations, which benefited the independent renewable energy generators.

However, it was not only the existence of a greater variety of political arenas that fostered the breakthrough of policies aimed at promoting decentralised energy generation technologies. This analysis has also been able to show that dispersive authority with regulatory power scattered between different political levels was also conducive to the successful implementation of such policies, once substantial regulations were in place. First of all, a division of regulatory competencies in energy regulation (i.e. concurrent legislation) between the federal and the state levels provided the latter with the scope and flexibility needed to set up a regulatory framework targeted at effectively and rapidly establishing renewable energy projects (especially wind power). This is reflected in the greater leeway that states had at their disposal for adapting the respective regulatory provisions (e.g. the planning system, the building laws and other project-relevant regulations such as nature conservation laws). The significance of this flexibility is illustrated by the fact that, with some time lag, the regulatory provisions of some states, which privileged the establishment of renewable energy projects, were later taken over by the federal government. Additionally, the existence of the political arena of the states guaranteed renewable energy generators continuity of support in the case when the federal level cut down the budget for renewable energy projects. In relation to the significance of the federal structure of government for successful implementation, it is necessary to keep in mind the crucial role played by the cartel offices in the different states: These forced the incumbent industry to observe the regulatory provisions laid down in the respective renewable energy acts. In this regard, one important factor for successful renewable energy policy also consisted in the possibility of enforcing the regulatory provisions in German courts. Furthermore, the implementation of the German Law was accompanied by the establishment of increasingly powerful interest groups in favour of renewable energy technologies. Together with the existing advocacy coalition for renewables operating close to the federal Parliament, these organisations were able to effectively defend the existing renewable energy policy. In fact, with the new reforms, initiated with the sectoral liberalisation in the late 1990s, they were even able to extend the scope of support policies.

Employing a critical and differentiated perspective, the article has analysed the often stated merits of unitary political-administrative systems: namely, that they can efficiently and rapidly initi- 
ate fundamental reform policies. It has shed some light on the negative characteristics associated with the ability to implement speedy reforms in sectoral policy. Whereas the ability to quickly open the market for competition was detrimental to the renewable energy policy in the United Kingdom, Germany was better able to implement substantial regulations precisely due to the lack of earlier liberalisation policies. In other words, the lack of ability of the German politicaladministrative system to quickly and substantially implement the respective market reform policies benefited political measures aimed at promoting innovative renewable energy technologies. Interestingly enough, although Germany has a weak regulatory approach on many infrastructure issues and seeks to open the market to competition via soft modes of regulation (Böllhoff 2002), it has strong environmental regulations, providing effective incentives for introducing renewable energy technologies onto the market. The situation in the United Kingdom is exactly the opposite. Here, they long had a rather strong regulatory policy, with specific regulators aiming to establishing competition in the generation and supply market, and a rather weak policy for making the electricity industry structure more sustainable. Given that the strong subsidies implicit in the German policy (i.e. their fixed feed-in tariffs) are at the core of the competitive policy debate about the best and most efficient practices for bringing renewable energy technologies onto the market, it will be very interesting to observe how the new renewable energy policy will perform in the United Kingdom. 


\section{References}

Baentsch, F. (1997): Umweltschutz im britischen Stromexperiment. Die umweltpolitischen Wirkungen der Strukturreform der britischen Elektrizitätswirtschaft hinsichtlich Schadstoffemissionen, Energieträgereinsatz und Energieeffizienz. Münster, Lit Verlag.

Bauer, M. W. (2002). Administrative Costs of Reforming Utilities (forthcoming). Regulating Utilities in Europe. The Creation and Correction of Markets. A. Héritier and D. Coen, Palgrave Press.

Bauknecht, D., S. Dendy and G. Doyle (2002): NETA statt Pool: Was hat der neue englische Strommarkt gebracht?, Marktplatz Energie, Nr. 3, Juni 2002.

Benz, A. and G. Lehmbruch (2001). Föderalismus. Analysen in entwicklungsgeschichtlicher und vergleichender Perspektive, Wiesbaden, Westdeutscher Verlag. PVS-Sonderheft 32/2001.

Bernstein, R. J. (1976). The Restructuring of Social and Political Theory, London, Methuen.

Böllhoff, D. (2002). Developments in Regulatory Regimes - an Anglo-German Comparison on

Telecommunications, Energy and Rail. Regulating Utilities in Europe. The Creation and Correction of Markets. A. Héritier and D. Coen, Palgrave Press.

Braun, D. (2002). Public Policy and Federalism. Aldershot, Ashgate.

Braun, D. (2000). Territorial Division of Power and Public Policy-Making: An Overview. Public Policy and Federalism. D. Braun. Aldershot, Ashgate.

Brundtlandt, G. H. (1987). Our Common Future. The World Commission on Environment\&Development. Oxford, Oxford University Press.

Bundesministerium für Umwelt, N. u. R. (2000). "Nationales Klimaschutzprogramm." Umwelt Nr. 11/2000.

Bundesministerium für Umwelt, N. u. R. (2002). Strategie der Bundesregierung zur Windenergienutzung auf See. Berlin, BMU.

Burgi, N. (1985). Neo-corporatist Strategies in the British Energy Sector. Organized Interests and the State. A. Cawson. London, Sage.

Chesshire, J. H. (1996). UK Electricity Supply under Public Ownership. The British Electrity Experiment - Privatization: the Record, the Issues, the Lessons. J. Surrey. London, Earthscan Publications Ltd.

Cleirigh, B. O. (2001). Evaluation of DTI Support for New and Renewable Energy under NFFO and the Supporting Programme. London, DTI, Frontier Economics. 
Coen, D. and M. Thatcher (2000). "Introduction: The Reform of Utilities Regulation in the EU." Current Politics and Economics of Europe 9, Number 3: 377-385.

Collier, U. (1994). Energy and Environment in the European Union - The challenge of integration. Aldershot, Avebury.

Collier, U. (1998). The Environmental Dimensions of Deregulation - An Introduction. Deregulation in the European Union. Environmental Perpectives. U. Collier. London and New York, Routledge: 3-22.

Currie, D. (1997). The Labour View. Regulating the Utilities: Broadening the Debate. M. E. Beesley.

Department for Transport, L. G. a. t. R. (2002). Planning Green Paper: Planning - Delivering a Fundamental Change. London, Department for Transport, Local Government and the Regions.

Department of the Environment, T. a. t. R. (2000). Climate Change - The UK Programme. London, Department of the Environment, Transport and the Regions.

Department of Trade and Industry (1998). A Fair Deal for Consumers. Modernising the Framework for Utility Regulation. London, Department of Trade and Industry.

Department of Trade and Industry (2000). Digest of United Kingdom Energy Statistics. London, The Stationery Office.

Department of Trade and Industry (2001). New \& Renewable Energy - Prospects for the 21st Century. The Renewables Obligation. Statutory Consultation. London, DTI.

Eberlein, B. (2000). "Configurations of Economic Regulation in the European Union: The Case of Electricity in Comparative Perspective." Current Politics and Economics of Europe 9, Number 3: 407-425.

Eising, R. (1999): Reshuffling Power: the liberalisation of the EU electricity markets and its impact on the German governance regime. The Transformation of Governance in the European Union. B. Kohler-Koch, R. Eising, London and New York, Routledge: 202-228.

Eising, R. (2000). Liberalisierung und Europäisierung - Die regulative Reform der Elektrizitätsversorgung in Großbritannien, der Europäischen Gemeinschaft und der Bundesrepublik Deutschland, Leske + Budrich, Opladen.

Eising, R. (2001). "Strategic action and policy learning in embedded negotiations: the liberalization of the EU electricity supply industry." Arbeitspapiere aus der FernUniversität Hagen polis Nr. 50/2001: 2-32.

Electricity Association (1999). The UK Electricity System. London, Electricity Association. 
Espey, S. (2001). Internationaler Vergleich energiepolitischer Instrumente zur Förderung regenerativer Energien in ausgewählten Industrieländern. Bremen. Bremer Energieinstitut.

Eurosolar (1995). "Die Selbstjustiz von Energieversorgungsunternehmen gegen das Stromeinspeisungsgsetz für erneuerbare Energie." Das Solarzeitalter 2/95: 2-27.

Eurosolar (1996). "Stromeinspeisungsgesetz verfassungsgemäß." Das Solarzeitalter 2/96: 30-33.

Eurosolar (1998). "Dritte Verfassungsklage zum Energiewirtschaftsgesetz: VEAG klagt gegen das Stromeinspeisegesetz." Das Solarzeitalter 3/98: 55.

Eyre, N. (1998). What Hope for a Sustainable Energy System? Man-Made Climate Change. Economic Aspects and Policy Options. O. Hohmeyer and K. Rennings. Heidelberg, New York, Physica-Verlag: 236-243.

Graham, C. (2000). "The Utilities Bill." Uitility Law Review 11 (3), May-June 2000: 92-103.

Groscurth, H.-M. and S. Weinreich (1998). Possible Contributions of Renewable Energies to the Solution of the Global Climate Problem. Man-Made Climate Change. Economic Aspects and Policy Options. O. Hohmeyer and K. Rennings. Heidelberg, New York, PhysicaVerlag: 219-235.

Helm, D. (2002). "A critique of renewables policy in the UK." Energy Policy 30: 185-188.

Hemmelskamp, J. (1999). Umweltpolitik und technischer Fortschritt - Eine theoretische und empirische Untersuchung der Determinanten von Umweltinnovationen. Heidelberg, Physica Verlag.

Henig, S. (2002). Modernising Britain. Central, Devolved, Federal? London, The Federal Trust.

Hall, P. A. (1992). The movement from Keynesianism to monetarism: Institutional analysis and British economic policy in the 1970s. Structuring politics. Historical institutionalsim in comparative analysis. S. Steinmo, K. Thelen and F. Longstreth. Cambridge, Cambridge University Press: 90-113

Héritier, A. (1993). Policy-Analyse. Kritik und Neuorientierung. PVS-Sonderheft 24/1993, Opladen, Westdeutscher Verlag

Héritier, A. and D. Kerwer, C. Knill et al. Differential Europe. The European Impact on National Policymaking. New York, Oxford, Rowman\&Littlefield

Héritier, A. and C. Knill (2000). Differential Responses to European Policies: A Comparison. Differential Europe. The European Impact on National Policymaking. A. Héritier, D. Kerwer, C. Knillet al. New York, Oxford, Rowman\&Littlefield. 
Hohmeyer, O. and K. Rennings (1998). Man-Made Climate Change. Economic aspects and Policy Options. Heidelberg, New York, Physica-Verlag.

Isherwood, B. (2002). Decentralisation, Devolution or Deconcentration: Alternative views of the modernisation agenda. Modernising Britain. Central, Devolved, Federal? S. Henig. London, The Federal Trust: 121-136.

Jasinski, P. and W. Pfaffenberger (2000). Energy and Environment: Multiregulation in Europe. Aldershot, Ashgate.

Jones, A. (2000). "Privatized Utilities and the 'Third Way'." Public Money \& Management 20(No. 3): 27-34.

Katzenstein, P., J. (1987). Policy and Politics in West Germany. The Growth of a Semisovereign State. Philadelphia, Temple Univ. Press.

Keating, M. (1999). The Politics of Modern Europe - The State and Political Authority in the Major Democracies. Cheltenham, UK, Edward Elgar.

Kohler-Koch, B. and R. Eising (1999): The Transformation of Governance in the European Union, London and New York, Routledge.

Lang, V. (1999). Die Regulierung der deutschen Stromwirtschaft: eine föderalismustheoretische Analyse. Frankfurt am Main, Lang.

Ledger, F. and H. Sallis (1995). Crisis Management in the Power Industry. An Inside Story. London and New York, Routledge.

MacKerron, G. and Pearson, P. (2000): The International Energy Experience. Markets, Regulation and the Environment. London, Imperial College Press.

Matláry, J. H. (1997). Energy Policy in the European Union, St. Martin’s Press, Inc.

Midttun, A. (1997). European Electricity Systems in Transition. A Comparative Analysis of Policy and Regulation in western Europe, Oxford, Elsevier.

Mitchell, C. (1996). Renewable Generation - Success Story? The British Electricity Experiment - Privatization: the Record, the Issues, the Lessons. J. Surrey. London, Earthscan Publications Ltd.: 164-184.

Mitchell, C. (2000). Renewables in the UK - how are we doing? The International Energy Experience - Markets, Regulation and the Environment. G. Mac Kerron and P. Pearson. London, Imperial College Press: 205-217.

Newman, I. (2002). The New English Regional Agenda and Europe. Modernising Britain. Central, Devolved, Federal? S. Henig. London, The Federal Trust: 147-164. 
Oberthür, S. and H. E. Ott (1999). The Kyoto Protocol. International Climate Policy for the 21st Century. Berlin, Springer-Verlag.

OFFER (1997). Review of Electricity Trading Arrangements - A Consultation Paper. 1997, OFFER.

OFFER (1998). Review of Electricity Trading Arrangements - Interim Consultations. London, Office for Electricity Regulation.

OFFER (1999): The New Electricity Trading Arrangements. Volume 1. London, Office of Gas and Electricity Markets.

OFGEM (2001a). The Renewables Obligation - OFGEM's Procedures. A Consultation Paper. London, OFGEM.

OFGEM (2001b). Report to the DTI on the Review of the Initial Impact of NETA on Smaller Generators. London, OFGEM.

OFGEM (2002). Report to the DTI of the Consolidation Working Group. London, OFGEM.

Paul, N. (2001). "Die Windenergie-Pioniere." Sonne, Wind \& Wärme 10-11/2001: 112-132.

Performance and Innovation Unit (2002). The Energy Review. London, Performance and Innovation Unit, Cabinet Office.

Prosser, T. (1999). "Theorising Utility Regulation." Modern Law Review 62: 196-217.

Pürtul, G. (2002). Meereswind in der Steckdose. Süddeutsche Zeitung. Munich: 2.

Renz, T. (2001). Vom Monopol zum Wettbewerb. Die Liberalisierung der deutschen Stromwirtschaft. Leske+Budrich, Opladen 2001.

Ross, C. (2000): The Promotion of Renewable Energy in England and Wales: the Use of the Non-Fossil-Fuel Obligation. In: Jasinski, P and W. Pfaffenberger. Energy and Environment: Multiregulation in Europe, Aldershot, Ashgate, 72-98.

Sabatier, P. A. (1993). Advocacy-Koalitionen, Policy-Wandel und Policy-Lernen - Eine Alternative zur Phasenheuristik. Policy-Analyse. Kritik und Neuorientierung. A. Héritier. Opladen, Westdeutscher Verlag GmbH. 24/1993: 116-148.

Schiffer, H.-W. (1997). Energiemarkt Bundesrepublik Deutschland. Cologne, Verlag TÜVRheinland.

Schneider, J.-P. (1999a). The German Model of Co-operative Energy Regulation. Hamburg. 
Schneider, J.-P. (1999b). Liberalisierung der Stromwirtschaft durch regulative Marktorganisation - Eine vergleichende Untersuchung zur Reform des britischen, US-amerikanischen, europäischen und deutschen Energierechts. Baden-Baden, Nomos Verlagsgesellschaft.

Staiß, F. (2000). Jahrbuch erneuerbare Energien. Radebeul.

Steinmo, S., K. Thelen and F. Longstreth (1992). Structuring politics. Historical institutionalsim in comparative analysis. Cambridge, Cambridge University Press.

Surrey, J. (1996). From Public to Private Ownership - Introduction. The British electricity experiment-privatization: the record, the issues, the lessons. J. Surrey: 3-13.

Taylor, A. (1992). "Issue Networks and the Restructuring of the British and West German Coal Industries in the 1980s." Public Administration 70 (1): 47-65.

Taylor, A. (1996). "The Politics of Energy Policy in the United Kingdom." Politics 16 (3): 133141.

Thomas, S. (1996). The Development of Competition. The British Electricity Experiment. Privatization: The Record, the Issues, the Lessons. J. Surrey. London, Earthscan Publications Ltd: 67-94.

Thomas, S. (1997). The British Market Reform. A Centralist Capitalist Approach. In: Middtun, A. European Electricity Systems in transition. A Comparative Analysis of Policy and Regulation in Western Europe, Oxford, Elsevier, 41-87.

Thomson, S. (2001). The Impacts of Climate Change: Implications for DETR. London, DETR.

Wachendorfer-Schmidt (2001). Politikverflechtung und politische Steuerungsfähigkeit. Beitrag zum PVS-Sonderheft 32/2001 'Föderalismus', Hg: Arthur Benz und Gerhard Lehmbruch. Heidelberg.

Young, A. (2001). The Politics of Regulation - Privatized Utilities in Britain. Warwick, Palgrave. 